\title{
Wage rigidities and business cycle fluctuations: a linked employer-employee analysis
}

Effrosyni Adamopoulou*, Emmanuele Bobbio, Marta De Philippis and Federico Giorgi

\author{
* Correspondence: \\ Effrosyni.Adamopoulou@ \\ bancaditalia.it \\ Bank of Italy, Directorate General for \\ Economics, Statistics and Research, \\ Structural Economic Analysis \\ Directorate, Via Nazionale 91, 00184 \\ Rome, Italy
}

\begin{abstract}
This paper analyses wage dynamics in Italy in the last 25 years with a special focus on the recent recession. Despite the rather rigid Italian institutional setting, using linked employer-employee data we find that wage rigidities, albeit always present, have been subdued during the recessionary years. Using complementary data, we verify that, although we only observe daily and not hourly wages, overtime hours are not the main mechanism behind this enhanced wage flexibility. We document the presence of a trade-off between wage and employment adjustments: firms historically displaying higher levels of wage rigidities were less able to modify wages but exhibited higher turnover. A higher share of temporary workers, whose contractual relationship may be costlessly terminated and whose wages are therefore more frequently negotiated, served instead as a significant wage flexibility enhancing margin. More broadly, we find that firms of larger dimension, with a higher share of blue collar workers, or belonging to a sector where bonuses represent a large part of annual earnings were the ones displaying a higher level of wage flexibility.
\end{abstract}

JEL Classification: J31, J33

Keywords: Wage dynamics, Negotiated wages

\section{Introduction}

Understanding what drives wage dynamics is important in order to explain why aggregate wages tend to be much less volatile over time than what standard macroeconomic models predict (Fig. 1). Moreover, it helps policymakers decide which policy interventions to prioritize during downturns. The relatively flat evolution of aggregate wages is usually explained through (i) the presence of wage rigidities, that is a well-known feature of many labour markets (see for example, Kahn 1997; Knoppik and Beissinger 2009; Devicienti et al. 2007; Dickens et al. 2007; and Holden and Wulfsberg 2008), and through (ii) cyclical changes in the composition of the workforce (Lemieux 2006), since lower-paid workers are usually more severely affected during recessions. Some recent literature (D’Amuri 2014; Adamopoulou et al. 2016; Daly et al 2011; Verdugo 2016) indeed finds that composition effects have driven up aggregate wages, particularly during the recent recession.

This paper focuses on wage rigidities and studies the distribution of wage changes for job stayers over the last 25 years, with a particular focus on the Great Recession. 


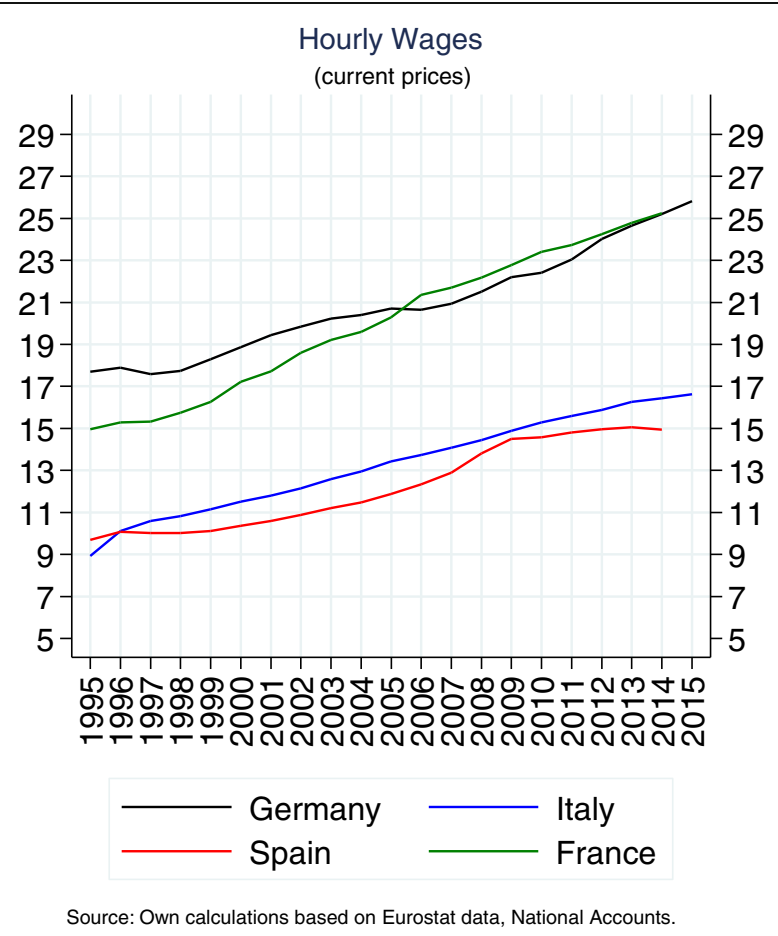

Fig. 1 Evolution of hourly wages over time

We evaluate the determinants of wage rigidities and we describe how firms, depending on their wage structure (e.g. share of bonuses on overall pay) and workforce composition, display very different levels of wage rigidity. Moreover, we study how firms reacted differently along the cycle, depending on their historical level of wage rigidity. In particular, we seek to answer whether firms which were structurally less able to adjust wages of job stayers reacted by adjusting employment more and whether these firms, by hiring new workers at a re-negotiated salary which corresponds more to the new cyclical conditions, managed to partially compress their average wage per employee, even in the presence of high levels of wage rigidity for stayers.

To measure rigidities in daily wages, we use newly available administrative employeremployee matched data for Italy that cover the years between 1990 and 2014. We rely on measures of wage rigidity based on the asymmetry of the distribution of yearly wage changes for job stayers and we find important adjustments in wages during the recessionary years (2009-2013). These adjustments were mostly driven by large firms and were mainly affecting blue collars. Moreover, using a unique hand-collected dataset on negotiated wages for employees in the metalwork industry and in the wholesale and retail industry, we document that the majority of these wage adjustments were enacted through the part of the wages that is not nationally negotiated. In addition, we show that changes in overtime hours per day are not the main driver behind our results.

In a second stage, we point out the large heterogeneity in the ability of firms to adjust wages and we study the determinants of this heterogeneity in the firm-level wage rigidity. We find that larger firms, with a higher share of blue collar workers, which belong to sectors whose wage structure is characterized by a larger amount of bonuses display more flexible wages. 
Finally, we show that more rigid firms reacted to the shock by increasing turnover more, but only if they were endowed with a flexible enough workforce, i.e. with a large share of temporary workers before the crisis. Presumably firms managed, even in the presence of high wage rigidity, to lower their average cost per employee by workers' replacement and wage renegotiation. ${ }^{1}$

Several previous studies have documented the existence of wage rigidities before the Great Recession. An important example is Kahn (1997), who uses US data and estimates that employees would experience nominal wage reductions $47 \%$ more frequently, absent wage rigidities. Dickens et al. (2007) analyse rigidities in the USA and in 15 European countries and find that the fraction of workers subject to wage rigidity is $28 \%$ on average, with very large heterogeneity across countries (from $4 \%$ in Ireland to 58\% in Portugal, Italy is in the middle of the distribution). By analysing wage rigidities during the recent downturn, we complement recent findings for the USA, the UK and Europe that find evidence of increased flexibility during the recent recession (Kurmann et al 2014; Brandolini and Rosolia 2015; Elsby et al. 2016; Verdugo 2016). We contribute to this literature by investigating more thoroughly which are the main determinants of wage rigidity/flexibility.

In addition, our paper speaks to the literature on the relationship between wage flexibility and employment. The available literature is much scarcer in this case and the evidence is mixed: Card and Hyslop (1997) find that wage rigidities have small effects on the economy, Pischke (2016) and Ehrlich and Montes (2015) find instead that wage rigidities are associated with lower employment levels. We contribute to this debate by exploiting the richness of our data in terms of variables and time span to study how firms responded to negative shocks, depending on their degree of wage rigidity and their workforce composition.

The structure of the paper is as follows: Section 2 briefly discusses the Italian institutional setting; Section 3 describes the datasets used for the analysis, and Section 4 studies the presence of wage rigidities for job stayers. Section 5 analyses separately the evolution of the nationally negotiated and the residual part of the wages. Section 6 estimates the relationship between wage adjustments, employment adjustments and the average wage per employee at the firm level. Finally, Section 7 concludes.

\section{Institutional setting}

The evolution of wages in Italy is strictly linked to its institutional setting of labour relations.

Since the income policy agreements of 1993, the Italian industrial relations are organized around two pillars. The first pillar is the national collective agreement (Contratto Collettivo Nazionale di Lavoro, CCNL), a sector-specific labour contract negotiated between the sector employers' association and the main trade unions. Its functions include the definition of the framework that disciplines the main aspects of labour utilization and the safeguard of real wage levels. The contracts are renewed every 3 years (since 2009, it used to be every 2 years before 2009) by the main social partners. Nominal increases of the base (minimum) wage are benchmarked to an independent 3year-ahead forecast of inflation net of imported energetic goods. The social parties agree on the level and the evolution of the base (minimum) wage to be applied to each occupation category (distinguishing various types of blue and white collar workers, as 
well as middle managers, depending on the sector) over the 3-year horizon. The second pillar is constituted by firm- or area-level labour contracts. Pay negotiations at the firm level are intended to account for firm-specific developments and local conditions, such as improved productivity or the risk of job loss. These are subordinate to the national one and can (i) modify items related to labour utilization, if the national contract allows them to, or regulate aspects not explicitly covered by the first level and (ii) provide for additional wage increases, which should both redistribute firm-level productivity gains (possibly achieved by the very same firm-level contract through more efficient organization) and align the labour cost to the ongoing labour market conditions. However, only in well-delimited cases of firm's restructuring or crisis, second-level deals can (temporarily) cut wages below the nationally set sectoral minimum. Still, although legally possible, there is little evidence of firm-level agreement envisaging a decrease in the wage below these minima during the period of our analysis (D'Amuri et al. 2015). Furthermore, despite the introduction of fiscal incentives to promote firm- and locallevel bargaining, these agreements are not very widespread (only $20 \%$ of firms with more than 20 employees in 2010) and are limited to larger firms and to specific sectors, respectively (D’Amuri et al. 2015).

This mechanism of wage negotiation inevitably results in some degree of downward wage rigidity as employers are constrained by the nationally negotiated minima agreed upon by the main social parties every 3 years. In case of a negative shock in firms' performance, this predetermination of wages over the contractual horizon by itself reduces the possibilities of timely adjustments, at least for the centrally bargained component. However, wages may still be flexible thanks to the part that is not centrally negotiated, representing on average $20 \%$ of wages. ${ }^{2,3}$

For what concerns the form of labour contracts, since 1997, the Italian labour market is characterized by the presence of both permanent and temporary contracts. However, although temporary contracts are becoming more widespread, more than $85 \%$ of all employees are still permanent ones. Depending upon the size of the firm (whether it is above 15 employees), there is also a relatively more stringent employment protection legislation regarding permanent workers (Cappellari et al. 2012). This somewhat limits the ability of firms to fire workers in case of a negative shock.

Therefore, wage rigidities and employment protection legislation interact in the evolution of wage and employment adjustments over the business cycle.

\section{Data}

The source for the data consists of social security payments made by legal entities to the Italian National Social Security Institute (INPS) for all employees with open-ended, fixed-term and apprenticeship contracts between 1990 and 2014. From this master data, INPS extracts two datasets. The first consists of the universe of firms with at least one employee at some point during a given calendar year-this extraction runs only up to 2013 and provides data at the firm level. The second consists of the employment histories of all workers born on the first or the ninth day of each month (24 dates). The firm extraction contains the fiscal code; information on the average number of employees over the year and the gross wage bill by occupational category-blue collar, white collar, middle and top manager; the two-digit sector code (NACE 2002) and the province code; and the date of entry and exit (if any). The worker extraction provides 
information on demographics, the annual gross wage, the number of days worked, maternity and sick leave as well as short time work benefits (STWB, Cassa integrazione guadagni) but only for the period 2005-2014. We restrict attention to the nonagricultural business sector and workers aged between 20 and 64 . We use the fiscal code as the definition of the firm. Tables 1 and 2 report the descriptive statistics for the sample of firms and workers respectively. Our sample of workers covers about $7 \%$ of the total workforce in the non-agricultural business sector while the firm data refer to the universe of firms with at least one employee (see Adamopoulou et al. 2016).

\section{Rigidities of nominal wages}

This section studies the evolution over time of wage rigidities in Italy in the nonagricultural business sector between 1990 and 2014. In line with the existing literature on wage rigidities (for Italy Devicienti et al. 2007), we restrict the analysis to the sample of "super-stayers" in order to analyse wage changes net of composition effects: we keep only full-time workers aged 20-64, who have worked for two consecutive years (for at least 52 weeks and at least 200 days per year), in the same firm, with the same contract

Table 1 Descriptive statistics, universe of firms paying contribution at INPS

\begin{tabular}{|c|c|c|c|c|c|c|c|c|}
\hline \multirow[t]{2}{*}{ Year } & \multirow{2}{*}{$\begin{array}{l}\% \text { of firms in } \\
\text { industry }\end{array}$} & \multirow{2}{*}{$\begin{array}{l}\% \text { of firms in } \\
\text { manufacturing }\end{array}$} & \multicolumn{2}{|c|}{ Wage per employee } & \multicolumn{2}{|c|}{ Firm size } & \multirow[t]{2}{*}{$N$ firms } & \multirow{2}{*}{$\begin{array}{l}\text { N employees } \\
(1000)\end{array}$} \\
\hline & & & Mean & $\mathrm{sd}$ & Mean & sd & & \\
\hline 1990 & 0.49 & 0.32 & 1102 & 457 & 7.96 & 182.3 & $1,116,992$ & 8891 \\
\hline 1991 & 0.48 & 0.32 & 1217 & 495 & 7.96 & 181.0 & $1,120,621$ & 8920 \\
\hline 1992 & 0.48 & 0.31 & 1288 & 539 & 7.86 & 188.1 & $1,122,468$ & 8823 \\
\hline 1993 & 0.47 & 0.31 & 1334 & 556 & 7.80 & 184.2 & $1,084,614$ & 8460 \\
\hline 1994 & 0.47 & 0.31 & 1382 & 579 & 7.83 & 180.2 & $1,059,329$ & 8295 \\
\hline 1995 & 0.47 & 0.30 & 1441 & 620 & 7.87 & 179.1 & $1,063,816$ & 8372 \\
\hline 1996 & 0.47 & 0.30 & 1492 & 646 & 7.94 & 172.9 & $1,069,946$ & 8495 \\
\hline 1997 & 0.46 & 0.30 & 1550 & 670 & 7.96 & 163.1 & $1,058,116$ & 8423 \\
\hline 1998 & 0.46 & 0.29 & 1580 & 697 & 7.97 & 156.2 & $1,082,872$ & 8630 \\
\hline 1999 & 0.45 & 0.28 & 1595 & 711 & 7.86 & 138.3 & $1,136,162$ & 8930 \\
\hline 2000 & 0.44 & 0.27 & 1637 & 766 & 7.97 & 139.1 & $1,181,332$ & 9415 \\
\hline 2001 & 0.44 & 0.27 & 1675 & 821 & 7.98 & 140.1 & $1,222,383$ & 9755 \\
\hline 2002 & 0.44 & 0.26 & 1693 & 788 & 7.73 & 133.2 & $1,293,290$ & 9997 \\
\hline 2003 & 0.44 & 0.25 & 1728 & 819 & 7.70 & 130.0 & $1,325,115$ & 10203 \\
\hline 2004 & 0.43 & 0.24 & 1765 & 837 & 7.59 & 127.9 & $1,369,569$ & 10395 \\
\hline 2005 & 0.42 & 0.24 & 1816 & 892 & 7.56 & 128.7 & $1,380,837$ & 10439 \\
\hline 2006 & 0.42 & 0.23 & 1872 & 938 & 7.55 & 132.0 & $1,403,806$ & 10599 \\
\hline 2007 & 0.42 & 0.22 & 1898 & 994 & 7.53 & 133.5 & $1,474,110$ & 11100 \\
\hline 2008 & 0.41 & 0.22 & 1973 & 1030 & 7.57 & 129.0 & $1,496,808$ & 11331 \\
\hline 2009 & 0.40 & 0.22 & 1975 & 1006 & 7.48 & 146.9 & $1,478,586$ & 11060 \\
\hline 2010 & 0.39 & 0.21 & 2031 & 1055 & 7.43 & 169.6 & $1,471,068$ & 10930 \\
\hline 2011 & 0.38 & 0.21 & 2068 & 1070 & 7.46 & 165.1 & $1,467,732$ & 10949 \\
\hline 2012 & 0.37 & 0.21 & 2073 & 1086 & 7.35 & 167.6 & $1,468,611$ & 10794 \\
\hline 2013 & 0.36 & 0.21 & 2100 & 1139 & 7.44 & 169.1 & $1,414,664$ & 10525 \\
\hline
\end{tabular}

Source: own calculations on INPS data for the universe of firms. Statistics of wages are weighted by the number of employees in the firm 


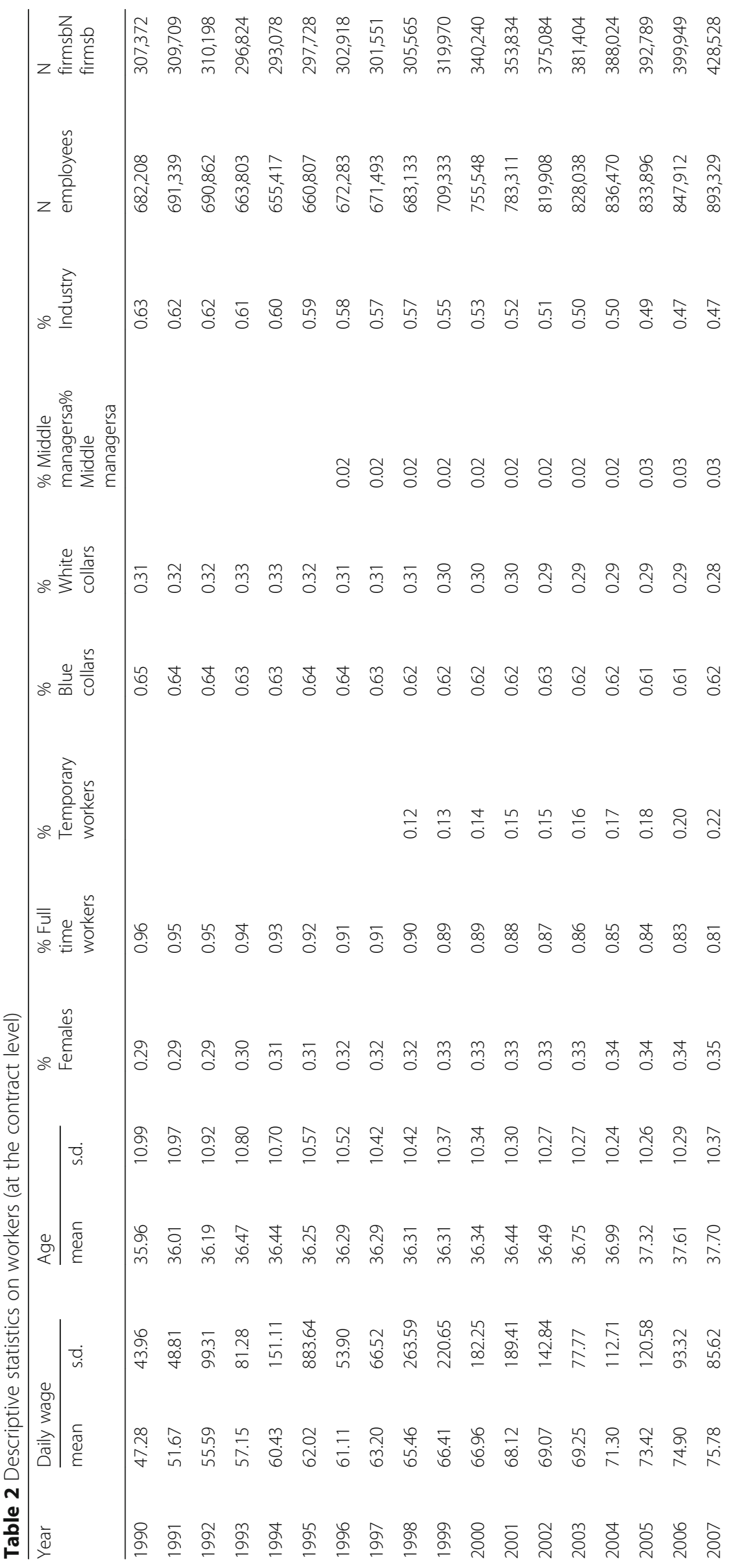




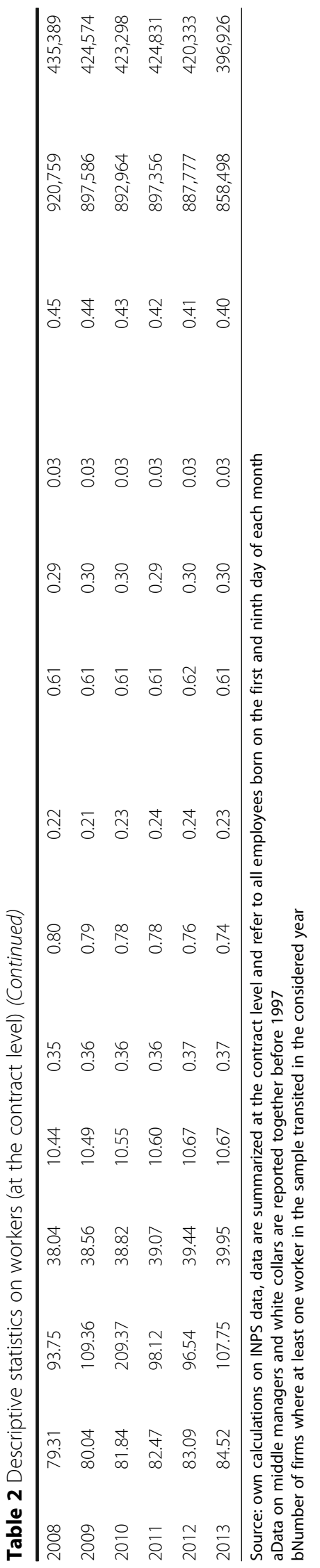


(full time/part time and fixed term/open ended) and position (blue collar/white collar/ middle manager) and who were not under short time work benefits (CIG/fondo di solidarietà; only since 2005 when the information becomes available). ${ }^{4}$ Excluding workers under short time work benefits is important when analysing the cyclicality of wage changes for stayers as these schemes are strongly anti-cyclical. Some other forms of measurement error in daily wage (level and/or change) remains inevitable, for instance, because of episodes of maternity or sick leave or because of adjustments in overtime hours. As long as this measurement error is not correlated with the business cycle, it should not pose a serious concern for our analysis that studies wage rigidity over time. We further show in a robustness exercise that changes in overtime hours that are likely to be correlated with the cycle do not affect our results.

We construct the daily wage for each worker by dividing the total annual wage by the number of days worked during the year, and we calculate the percentage change in daily wages for the sample of workers defined above. ${ }^{5,6}$ We exclude the outliers of the daily wage changes distribution (1st and 99th percentile).

The upper panel of Fig. 2 plots the distributions of the annual change in daily wage for 2006 (before the first part of the recession) and 2009 (during the first part of the recession). Each plot includes a solid vertical line at 0 to denote the threshold for nominal wage rigidities, a dotted vertical line at the inflation rate to denote the possible threshold for real wage rigidities and a dashed one that is a proxy of aggregate productivity developments (annual percentage change of value added per worker). We observe that in 2006, the distribution is skewed to the right, implying that the mass of employees who experienced a wage change above the median is larger than the mass of those who experienced a wage change below the median. The peak of the distribution is around the inflation rate, and there is an "excessive" concentration between zero and the inflation rate. Moreover, the share of employees who received a daily wage cut in 2006 is significantly lower. Instead, in 2009, the distribution shifts to the left and becomes much more symmetric. The lower panel of Fig. 2 presents the distributions of the annual change in daily wage for 2010 (a period of slight recovery) and 2013 (during the second part of the recession). We observe that the mass of the distribution shifted to the right as soon as there was a slight recovery in 2010 but shifted again to the left in 2013.

\subsection{The measures of wage rigidity}

In this paper, we adopt a flexible approach for the estimates of wage rigidities: the only assumption we make is that the distribution of the notional wage changes is symmetric around the median. ${ }^{7}$ This implies that the only thing that distinguishes a scenario of rigid wages from a scenario of fully flexible wages is the presence of asymmetries in the distribution of wage changes. The assumption that the distribution of the notional wage changes is symmetric is in line with a large strand of the literature that adopts more parametric approaches (Dickens et al. 2007; Goette et al. 2007; Devicienti et al. 2007; Card and Hyslop 1997). Our methodology, adopted also by Verdugo (2016) to study wage cyclicality in Europe, differs because it does not make any parametric assumption on the mean and variance of the notional wage changes distribution. We just assume that, absent wage rigidities, the bottom half of the distribution would mirror the upper 

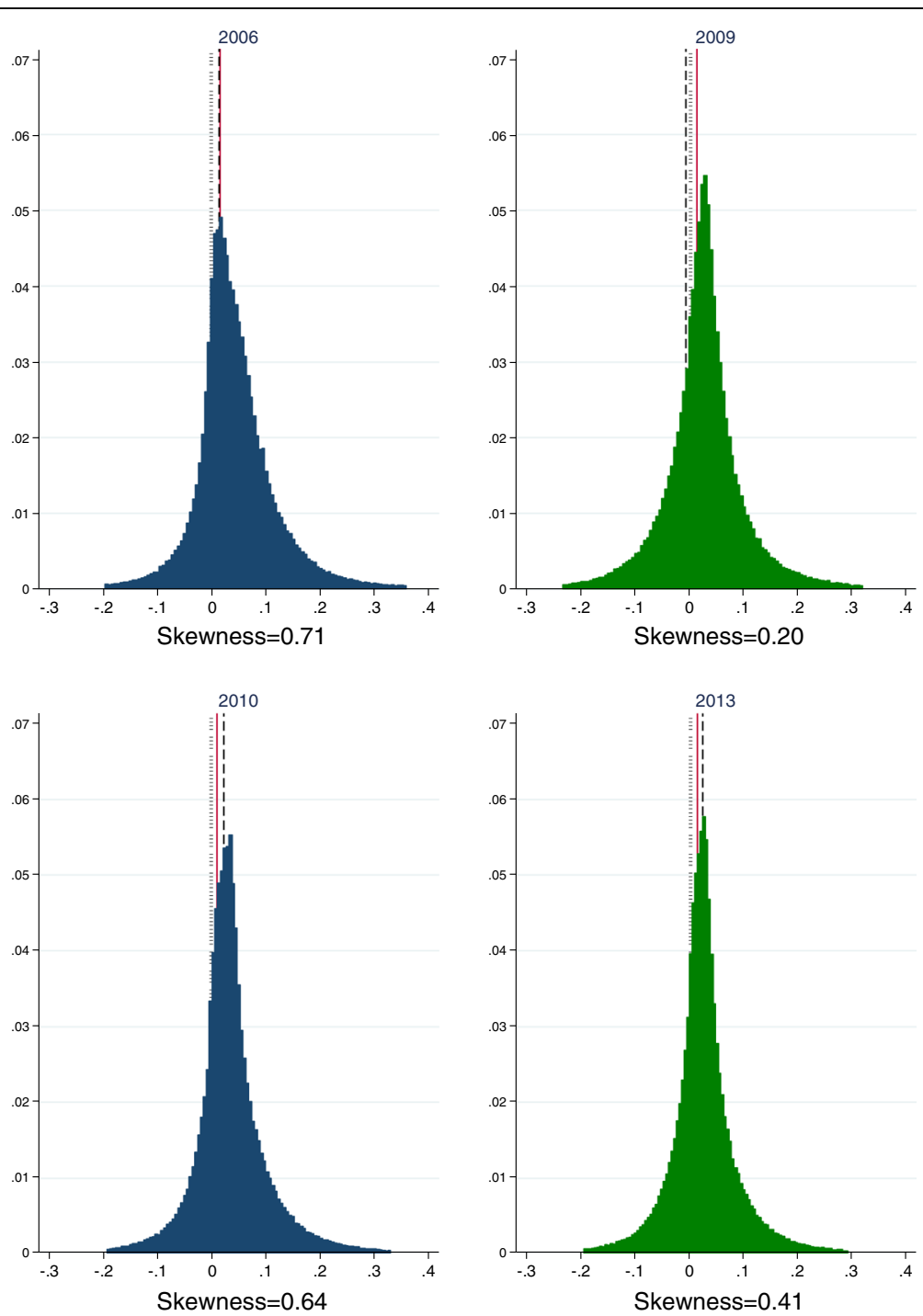

Source: own calculations on INPS data (on the sample of job stayers).

Notes: The solid vertical line corresponds to the 0 threshold for nominal wage rigidities,

the dotted vertical line corresponds to the inflation rate threshold for real wage

rigidities and the dashed line corresponds to aggregate productivity developments

(annual percentage change of value added per worker).

Fig. 2 Distribution of percentage annual change of daily wages, private non-agricultural sector

half. For instance, we allow the mean and the standard deviation of the notional wage change distribution to freely vary over time.

Moreover, in this paper, we decided not to distinguish between nominal and real wage rigidities because they are usually identified by observing spikes either around 0 or around the inflation rate. However, since we are considering years of very low inflation, it is difficult to separately identify the two types of rigidities (see Devicienti et al. 2007).

Therefore, all measures of wage rigidity we use are based on the notion that the notional wage changes distribution is symmetrically distributed around the median and that observing a missing mass below 0 (or below the inflation rate) implies higher level of wage rigidities. First, we use the classical measure of asymmetry of a distribution, its 
skewness. Second, we compute the so-called Kelley's skewness. This alternative measure of the asymmetry of a distribution relies on the quantiles of the distribution, and it has the advantage of being robust to extreme observations (it was proposed by Guvenen et al. 2014 and adopted also by Verdugo 2016). It is computed as the relative difference between the upper and lower tail densities (L90-50-L50-10)/L90-10. A negative number indicates that the lower tail is larger than the upper tail, and vice versa for a positive number. This measure has also the advantage of accounting for measurement error or changes in hours worked that may emerge as outliers in the data. Finally, as a robustness check, we look at the percentage of employees with a recorded negative wage change, which is used by Elsby et al. (2016) to analyse wage adjustments and wage rigidity in the USA and in the UK during the crisis.

While the first two measures are positively related to rigidity (i.e. a distribution of delta wages skewed towards the left), the last one is negatively related to rigidity.

\subsection{Possible confounding factors}

We now discuss which other factors, apart from the actual flexibility of hourly wages, may lie behind the observed changes in daily wages. Daily wages may vary because of changes in the hourly wage or because of changes in hours per day (e.g. overtime):

$\Delta$ daily $w \approx \Delta h * w+\Delta w * h$,

where $h$ are hours of work per day and $w$ is hourly wage (which is partly negotiated at the national level and partly decided at the firm level). Kurmann et al. (2014) show that adjustments in hours were relevant in explaining adjustments of daily wages, at least in the USA.

The INPS data do not contain information on hours worked per day that would allow us to verify whether the decrease in daily wages has been accompanied by a decrease in hourly wages. We therefore seek information from external sources. First, we evaluate the importance of overtime pay on total wages, using the Structure of Earnings Survey in 2006. We find that overtime pay accounted for a relatively low portion (around 4\%) of monthly earnings in the industrial sector, excluding construction. Even if this amount is modest, adjustments in overtime hours may still account for a significant fraction of observed daily wage changes. However, in Section 6.1, we use data on the universe of workers employed in a sub-sample of firms ${ }^{8}$ for which we observe the overtime and total hours, and we find that overtime (as a fraction of total hours) is uncorrelated with the degree of wage rigidity at the firm level. This suggests that overtime hours are not associated with wage flexibility.

Another source of possible measurement error comes from una tantum payments, which are lump sum top-ups paid in case of delays in the renewal of the collective contract. These payments (una tantum) that range between a few hundred up to more than one thousand euros could result in positive wage changes in the year when they are paid, followed by spurious negative wage changes in the year after. Since many contracts were renewed in 2008, una tantum payments could induce a fictitious decline in the observed wage flexibility in 2009 , at the time when the crisis hit the Italian economy. The INPS data do not contain separate information on the different components of wages and in particular on una tantum payments. We therefore use external information on una tantum payments published by the Italian National Statistical Institute 
(ISTAT) to net our wage measure from this component. Figure 3 shows that the distribution of wage changes remains practically unaffected in 2009 and in 2006, once we exclude these top-ups.

\subsection{Results}

From Fig. 2, it is already possible to evaluate how the symmetry of the distribution has changed during the recent crisis. The figure indeed points towards a partial increase in wage flexibility during the recession, in line with the findings of Brandolini and Rosolia (2015) and Verdugo (2016) for the EU and the ones of Kurmann et al. (2014) for the USA and the UK. The skewness declined from 0.7 in 2006 to 0.2 in 2009; it then

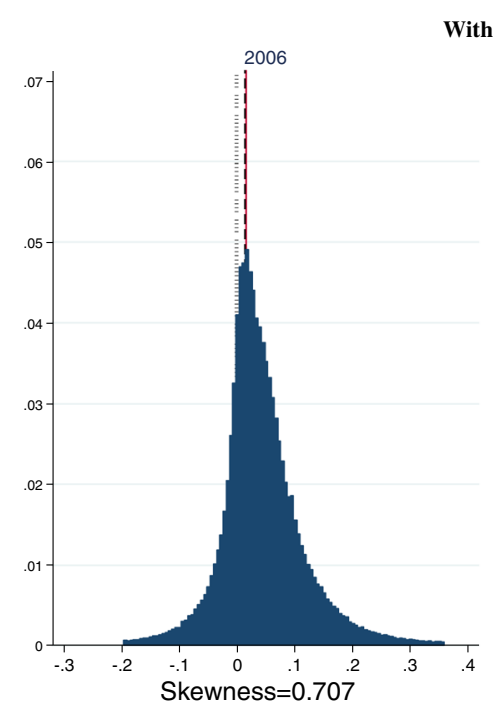

With una tantum
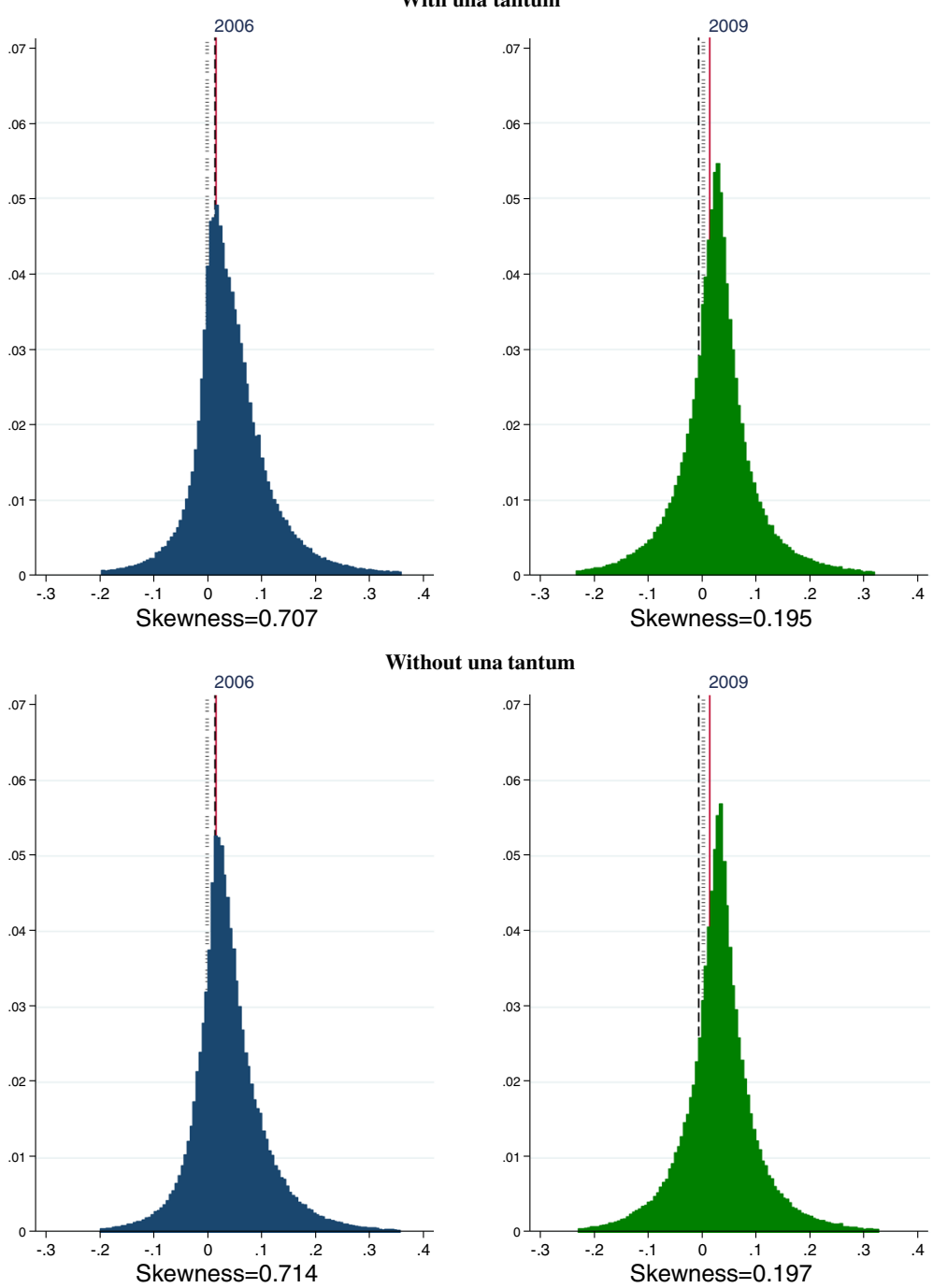

Source: own calculations on INPS data (on the sample of job stayers).

Notes: The solid vertical line corresponds to the 0 threshold for nominal wage rigidities,

the dotted vertical line corresponds to the inflation rate threshold for real wage

rigidities and the dashed line corresponds to aggregate productivity developments

(annual percentage change of value added per worker).

Fig. 3 Distribution of percentage annual change of daily wages, private non-agricultural sector, with and without una tantum 
increased back to 0.6 in 2010 and dropped to 0.4 in 2013. Overall, wage rigidities seemed to be subdued during the period 2009-2013 compared to the pre-recessionary years. Such flexibility was not reflected in aggregate wages possibly because composition effects have dominated (Adamopoulou et al. 2016).

Figure 4 reports the evolution of our three different measures of rigidity in the last 25 years for employees in the private sector excluding agriculture. Both the first (dashdotted line) and the second (solid line) measure display a drop after 2009, showing that the distribution of annual wage changes became less asymmetric to the right. The percentage of employees with a recorded negative wage change (dashed line) mirrors these measures by featuring an increase after 2009. Almost $30 \%$ of job stayers have a recorded negative wage change in 2009 while this figure is around $20 \%$ in normal times. ${ }^{9,10,11}$ Overall, the coherence between these three measures of rigidity is high: the simple correlation between Kelley's skewness and the standard measure of skewness is 0.9 and that with the share of wage cuts is 0.3 . Given the frequent presence of outliers in wage changes, in the rest of the paper, we report only the Kelley's skewness and the share of employees with recorded negative wage change. The results with skewness are available upon request.

These measures of skewness for the overall private non-agricultural sector may mask considerable heterogeneity across different types of workers or firms. Figure 5 shows the evolution of Kelley's skewness for employees in different positions: blue collars, white collars and middle managers. We observe that the skewness decreased more for blue collars (dashed line). White collars and middle managers were affected to a lesser extent. The percentage of employees with a recorded negative wage change rose after 2009 especially among middle managers (Fig. 6). This may be due to the high incidence of bonuses for this particular category of workers, which allowed firms to cut wages more homogeneously, shifting the distribution of wage changes to the left without affecting its shape as much as for other occupational categories.

Regarding differences across sectors, we observe that employees in the industrial sector excluding construction experienced more wage cuts during the recessionary years and the largest drop in the skewness of the distribution of wage changes (Figs. 7 and 8). ${ }^{12}$ Lastly, we observe important differences between firms of different sizes (Figs. 9 and 10) in line with the findings of Adamopoulou et al. (2016). In particular,

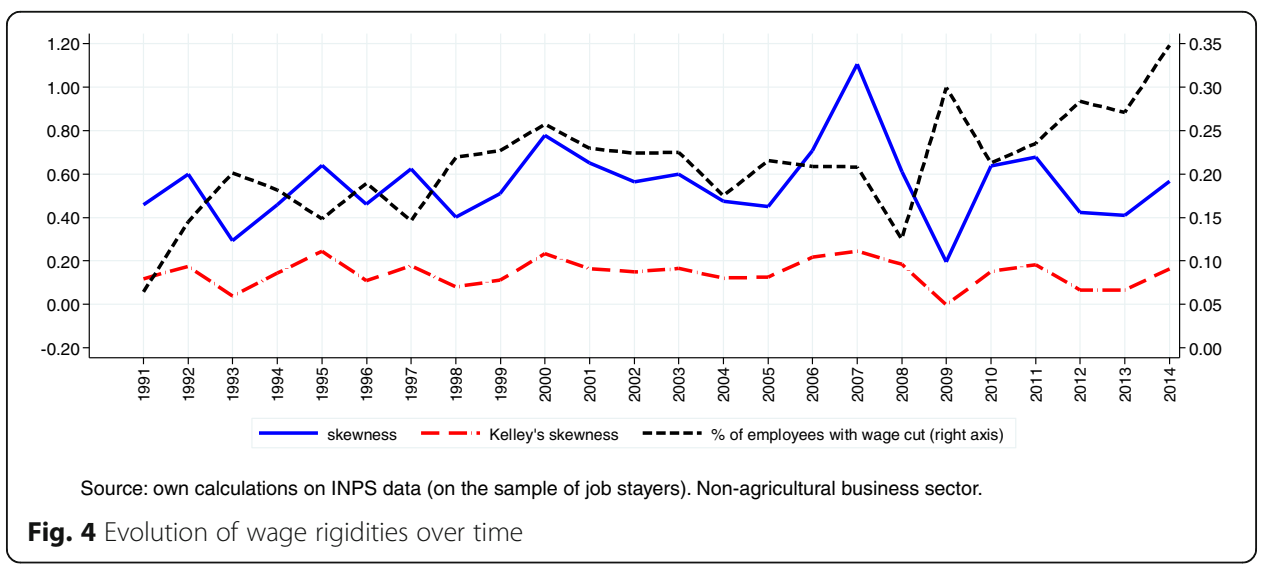




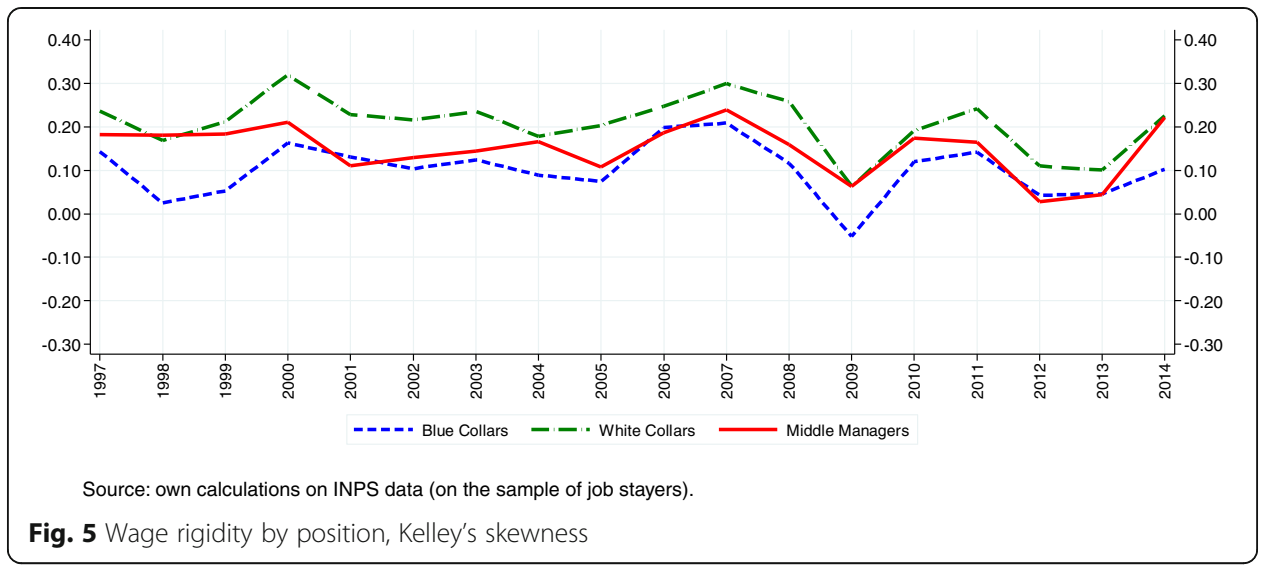

medium-sized and large firms managed to reduce wages more than small firms, possibly due to the larger share of bonuses related to firms' performance. ${ }^{13}$ This result is consistent with what found with the skewness measure with the exception of very large firms (with 250 employees or more). These firms usually display a higher level of flexibility, but their distribution of wage changes experienced a smaller drop in the skewness during the crisis. The discrepancy between the evolution of the skewness and of the percentage of employees with a recorded negative wage change in very large firms again may be due to the fact that large firms pay wages on average well above the minimum and were able to adjust wages more homogeneously.

All in all, we document the presence of some degree of higher wage flexibility during the recent recession even in a context like the Italian one where some institutional features of the labour market, like the way wages are bargained, may make wages rather rigid. In the next section, we focus on a case study in order to understand better how wages were adjusted in such an institutional environment.

\section{Wage drift}

As mentioned above, wages are made up of two components, a nationally negotiated base wage and a residual part set at the firm level. On average, in Italy, they account for about 80 and $20 \%$ of total wage, respectively; half of the firm level component comes in the form of bonuses (Structure of Earnings Survey, 2006). ${ }^{14}$ This section

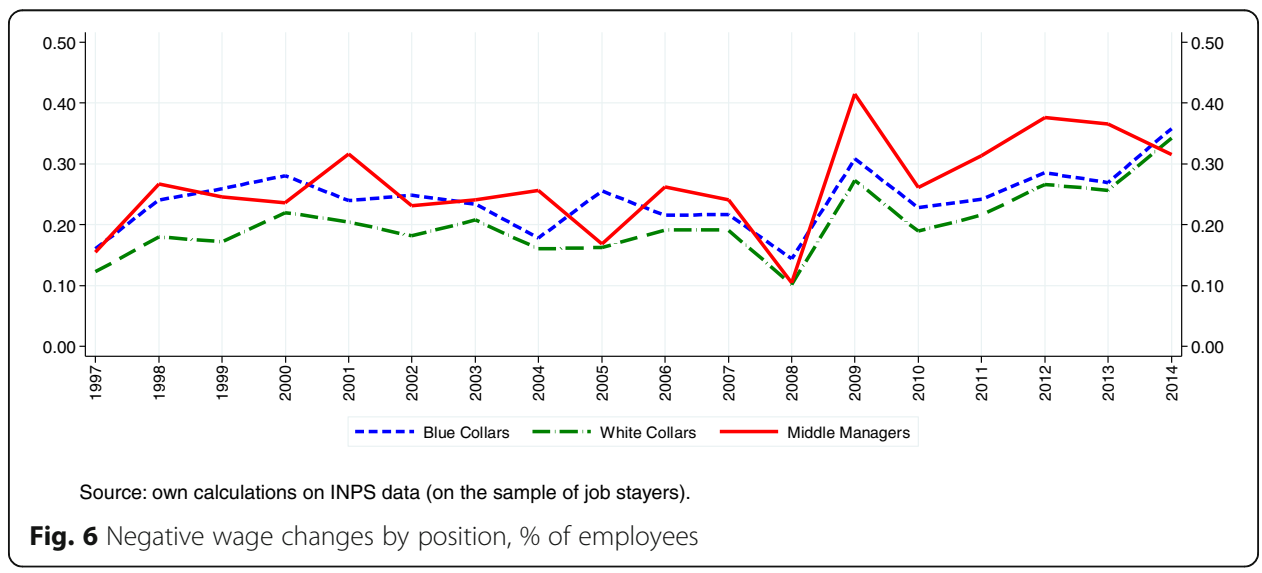




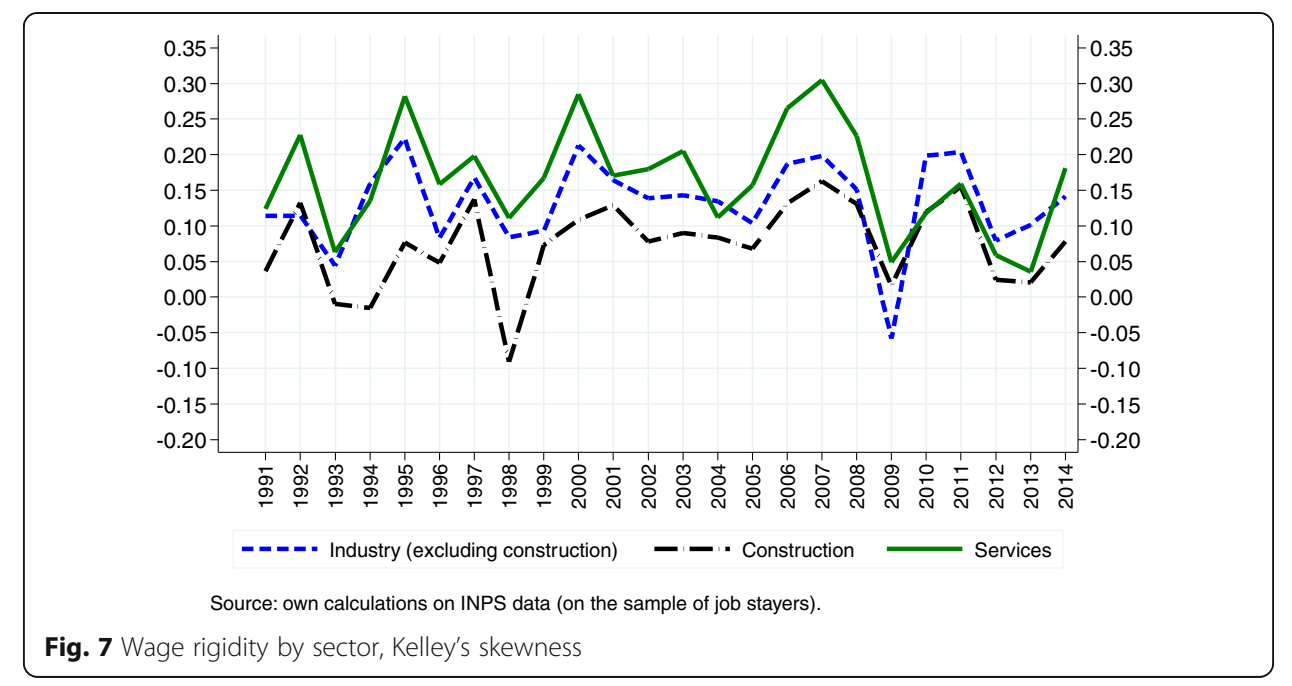

studies the different behaviour of the nationally negotiated and the residual part of daily wages, as well as the way they interact with each other, to pin down possible mechanisms behind the higher wage flexibility for different types of workers and firms.

INPS wage data lack separate information on the various components of wages in order to understand where the flexibility comes from. We separate the two parts using a unique dataset that has been hand-collected ${ }^{15}$ and provides us with information over time about negotiated wages for two national contracts: metalwork industry and wholesale and retail trade. These national contracts cover respectively around 25 and $15 \%$ of all employees in the private non-agricultural sector in Italy. As described in Section 2, negotiated wages set minima for workers according to their sector and contractual position. In the INPS data, we identify blue collars, white collars and middle managers. Since in the national contracts, these categories are finer (there are three categories for blue collars, four categories for white collars and two for middle managers), we need to aggregate them in order to match them with the social security data. Although this aggregation may result in some measurement error, this is less of a problem when we

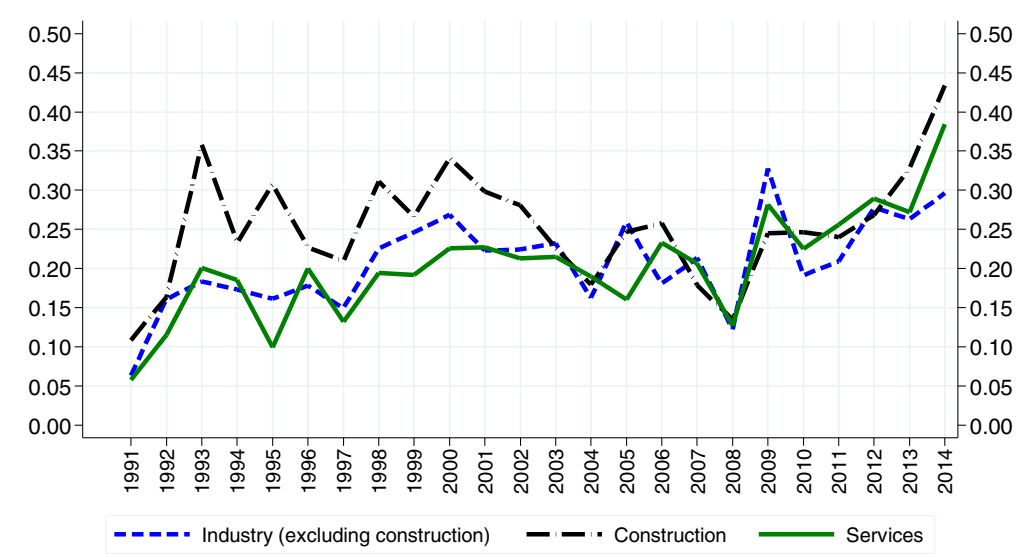

Source: own calculations on INPS data (on the sample of job stayers).

Fig. 8 Negative wage changes by sector, \% of employees 


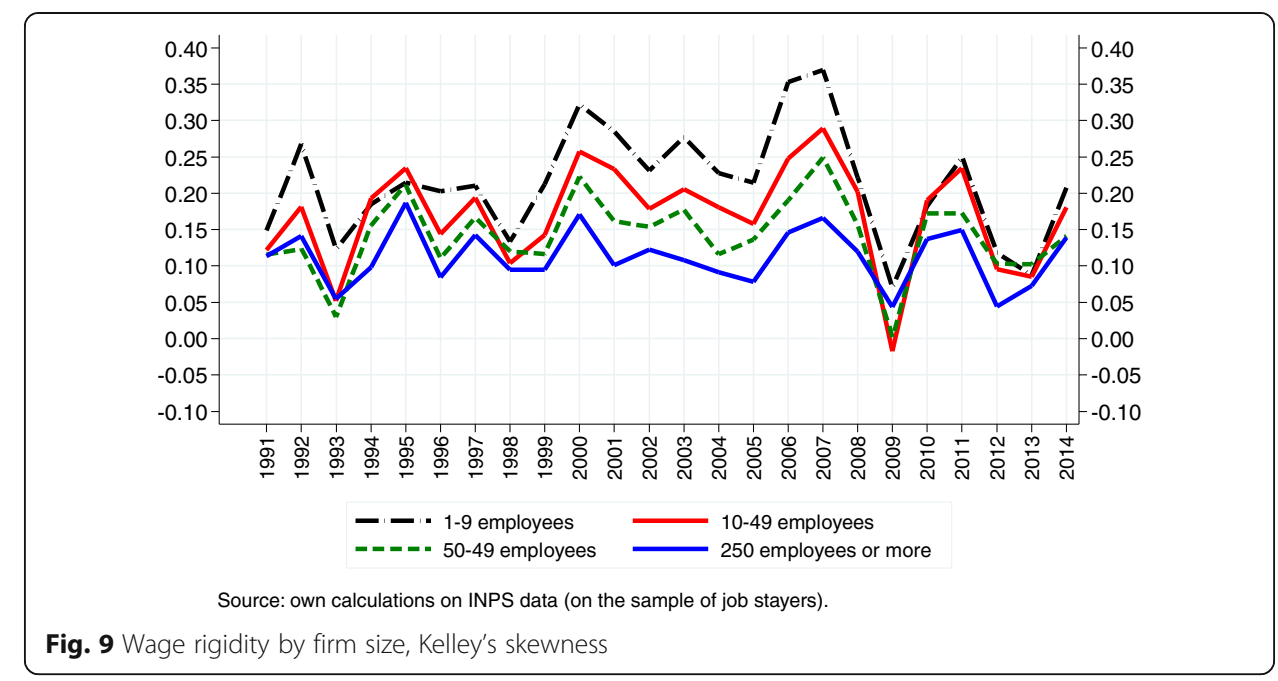

look at wage changes instead of wage levels, since the agreed percentage changes are usually similar across broad positions.

Figures 11 and 12 show the evolution of the part of the wage that excludes the nationally negotiated minima in each sector by the employees' position (black line). Among metalworkers, we observe a large drop in 2009, i.e., at the onset of the crisis, for blue collars and white collars while middle managers were only mildly affected. In 2014, there is another drop, but only for blue collars. By contrast, those that suffered mostly in 2009 among the employees in the wholesale and retail trade were the middle managers. Blue collars and white collars experienced instead a large drop in 2014. These different reactions in the residual part of wages may reflect sectorial differences in the structure of wages (bonuses) and/or overtime hours. The nonnegotiated part of wages is larger for large firms, for workers in the metalwork industry and for middle managers.

We then repeat the exercise of the previous section and calculate measures of the skewness using the part of the wage that is not negotiated at the national level rather than the total wage. As expected, the residual part of the wage is on average, more

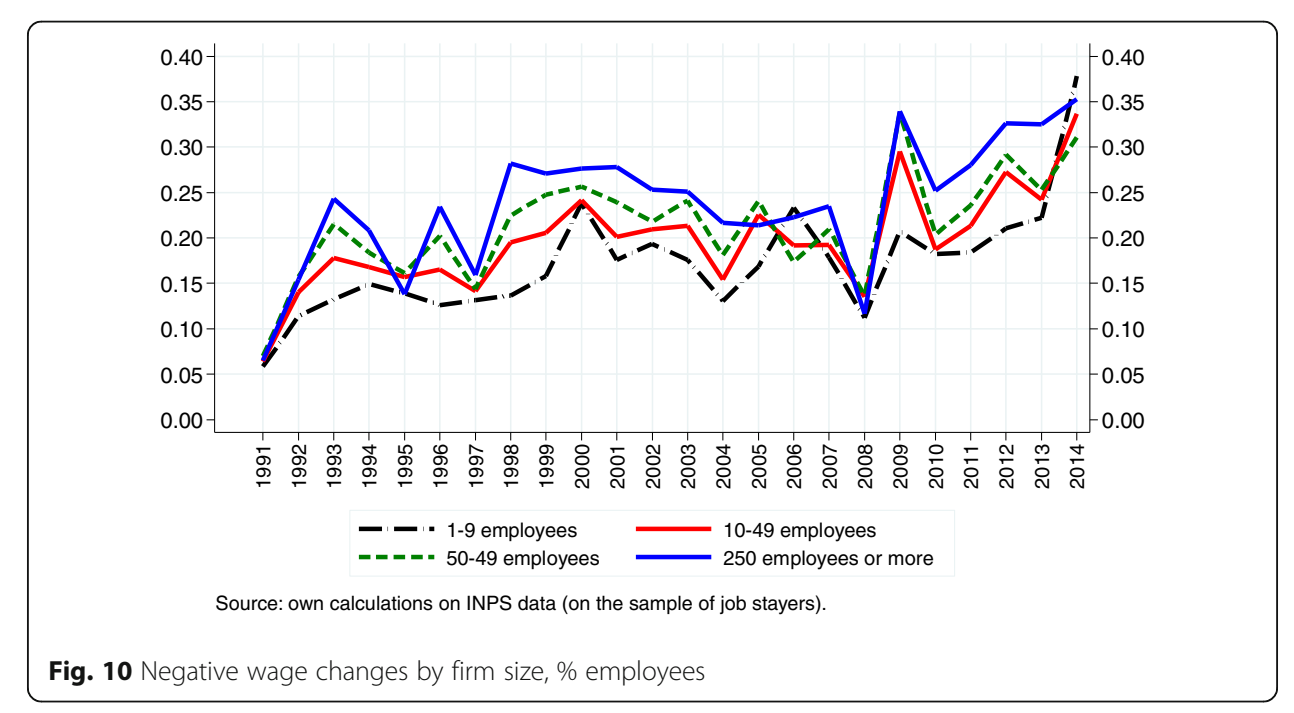




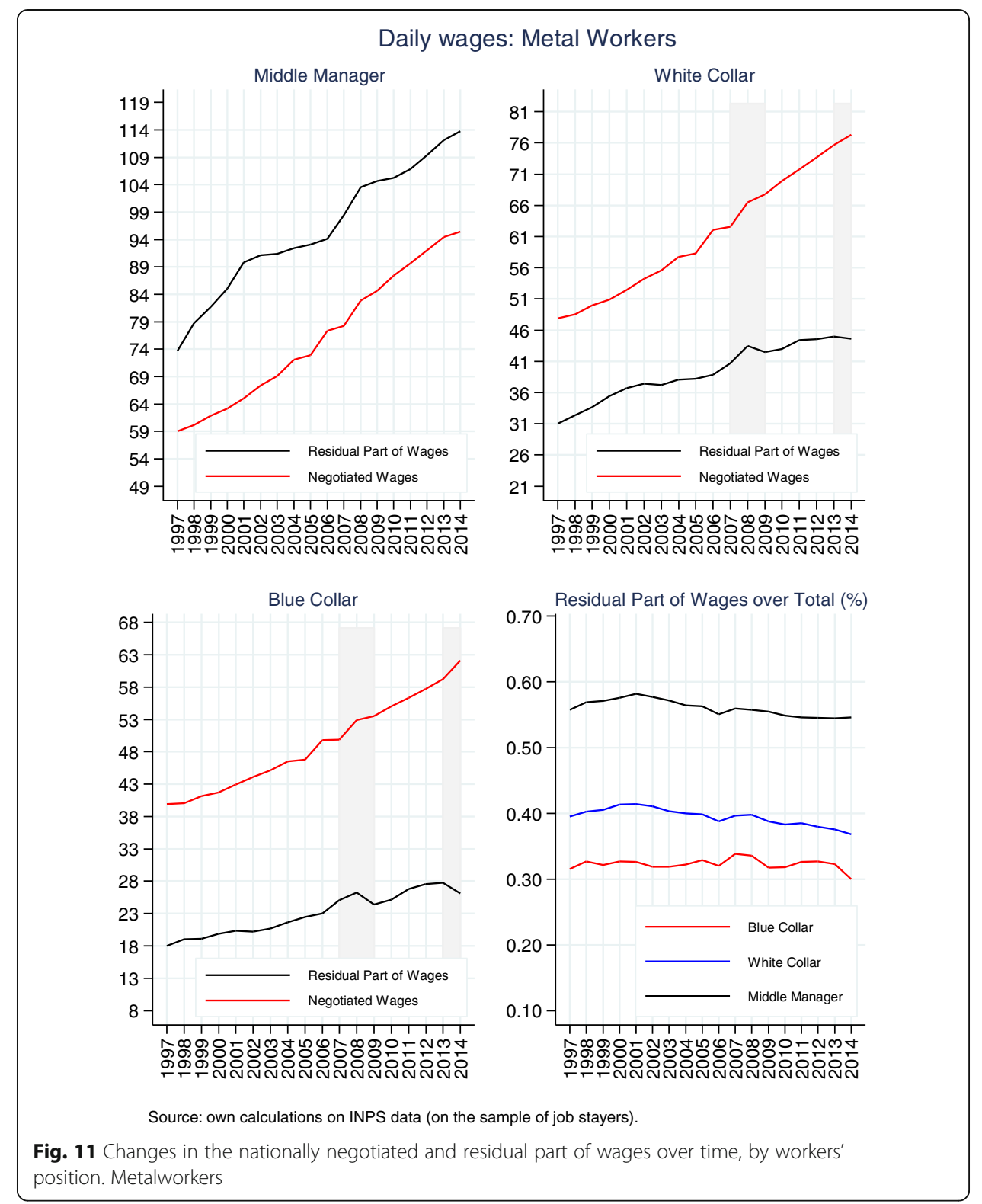

flexible (the level of skewness associated with it is lower and the share of wage cuts is higher). In particular, in 2006, the Kelley's skewness in the wholesale and retail trade sector was 0.07 for the residual part and 0.31 for the overall wage $(0.02$ and 0.14 for the metalwork industry). Moreover, in line with our previous graphs, we observe that the skewness of the residual part of wages decreases, even towards negative values, in 2009, especially among blue collars in the metalworkers contract and among middle managers in the wholesale and retail trade sector.

The information on the negotiated and residual part of the wage also allows us to investigate whether an increase in the negotiated wage induces firms to adjust the other component of the wage. The red line in Figs. 11 and 12 represents the negotiated part of the wages. Note that due to the institutional setting, the evolution of the negotiated part of the wages is sticky as it is usually predetermined for 3 years. As a result the negotiated part of the wages continued to rise even during years of economic downturn 


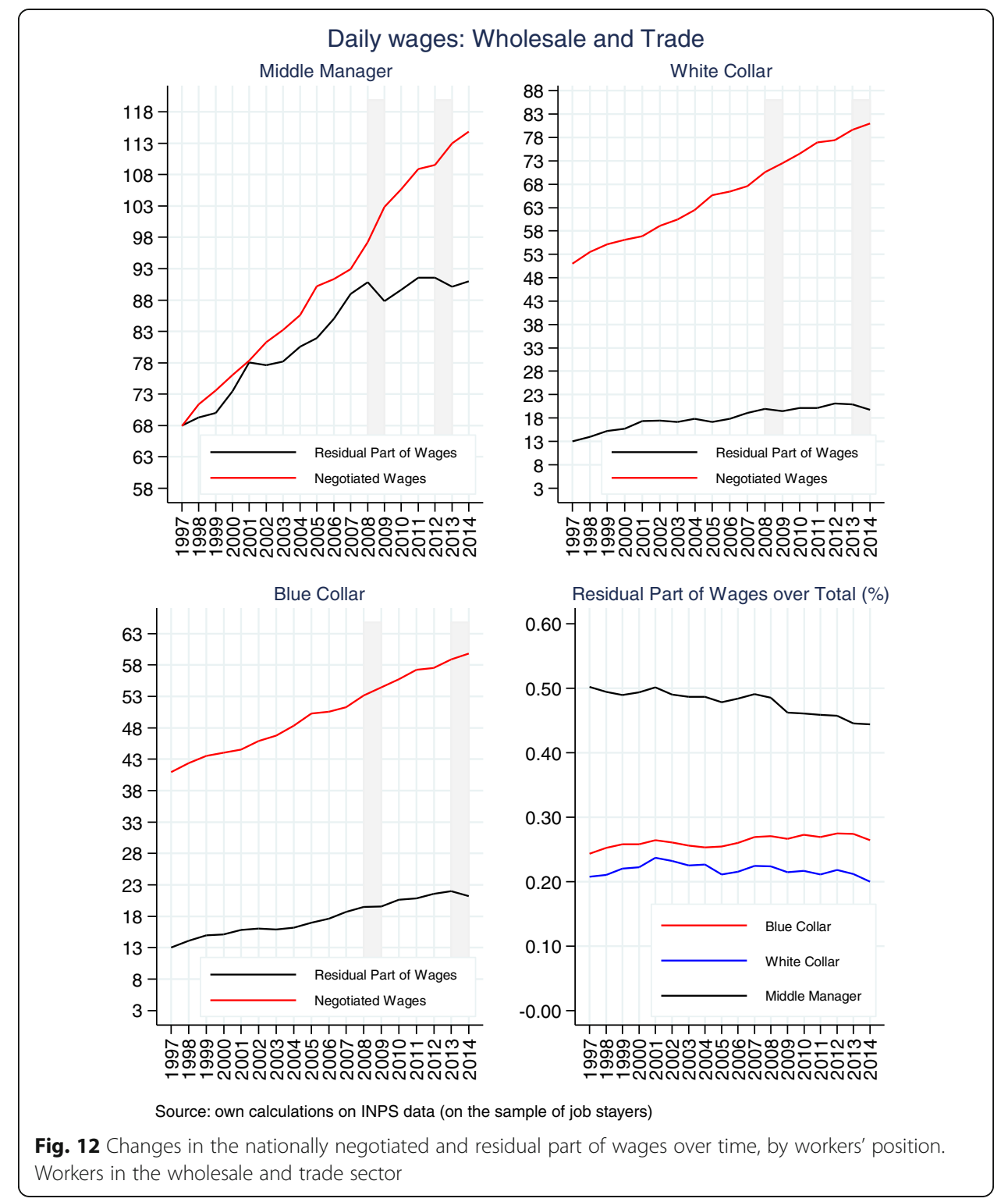

(grey area). ${ }^{16}$ However, a simple graphical inspection of the evolution of the negotiated (red line) and residual (black line) part of the wages shows that in 2009 and in 2014, firms compensated for the increase of the negotiated part of the wages by reducing the residual component. ${ }^{17}$

\section{Wage rigidities, employment adjustments and firms' average employee compensation}

Wage rigidities may induce firms to perform adjustments along the employment margin as an alternative way to react to shocks. Devicienti et al. (2007) find that in the 1990s, firms with higher downward rigidities in Italy tended to display higher worker reallocation rates in terms of turnover. In this section, we study whether firms that are historically characterized by high wage rigidities adjusted employment more during the recent recession and whether in this way they managed to contain their average wage per employee. 
To do so, we make use of an alternative dataset that covers the universe of employees for a sample of firms with more than 20 employees. Observing the universe of employees in each firm is crucial in order to define an accurate measure of wage rigidities at the firm level. These data come from INPS as well, and refer to the universe of employees in the firms that belong to the Bank of Italy's yearly survey on industrial and non-financial service firms (INVIND), and consist of around 4000 firms per year. Another advantage of using this dataset of employees is that we can enrich it with extra variables at the firm level that come directly from the INVIND survey. For example, INVIND allows us to separately observe accessions and separations that could only indirectly and partially be proxied by monthly employment changes in the INPS firm data. Moreover, INVIND provides us with additional information, like total sales (in euros) that can serve as a demand-shift control. There is also information on per capita overtime hours that can help us verify that the wage adjustment is not operated through this channel only. ${ }^{18}$

\subsection{Wage rigidity: firms' heterogeneity}

We now dig into the determinants of wage rigidity. In particular, we study how the degree of wage rigidity differs among firms and which characteristics of the firm determine such heterogeneity.

In order to perform this analysis, we need to compute a measure of wage rigidity at the firm level. In particular, we aim at constructing a measure that summarizes the firms' ability to adjust wages of incumbents when hit by a shock, for example, because of higher bonuses or higher bargaining power. Similarly to what we did in Section 4, we base our measure on the asymmetry of the distribution of wage changes before the crisis. For each firm belonging to the INVIND sample, we compute the Kelley's skewness of the distribution of yearly wage changes for job stayers and we average across the years between 2003 and 2008. This measure relies on the same assumptions described in Section 4. Positive values of the skewness are associated with the presence of wage rigidities, while values close to 0 point towards wage flexibility. We exclude all firms with few job stayers (less than 80 in the period 2003-2008) because the skewness measure would not be reliable if the number of observations in the distribution of wage changes is too small. ${ }^{19}$ Figure 13 shows how our firm-level measure of wage rigidity is distributed. The mean is larger than 0 (it is 0.13 ), implying that it exists some form of wage rigidity on average. Moreover, there is a high level of heterogeneity across firms (the standard deviation is 0.19 ).

We consider three main factors behind differences in wage rigidity across firms: the presence of a large component of bonuses; the extensive use of overtime hours, which are easier to adjust during downturns; and the actual ability to adjust the base salary of job stayers, due to high bargaining power, for instance. Figure 14 shows how our measure of rigidity is correlated with the amount of bonuses (over annual earnings) at the sector level. The figure displays on the $x$-axis the share of bonuses over earnings as obtained from the Structure of Earnings Survey in 2006 and on the $y$-axis our measure of wage rigidity averaged at the sector level. There is a negative correlation: those sectors whose wage structure is on average characterized by a high share of bonuses are the ones that according to our measure of wage rigidity are more flexible. 


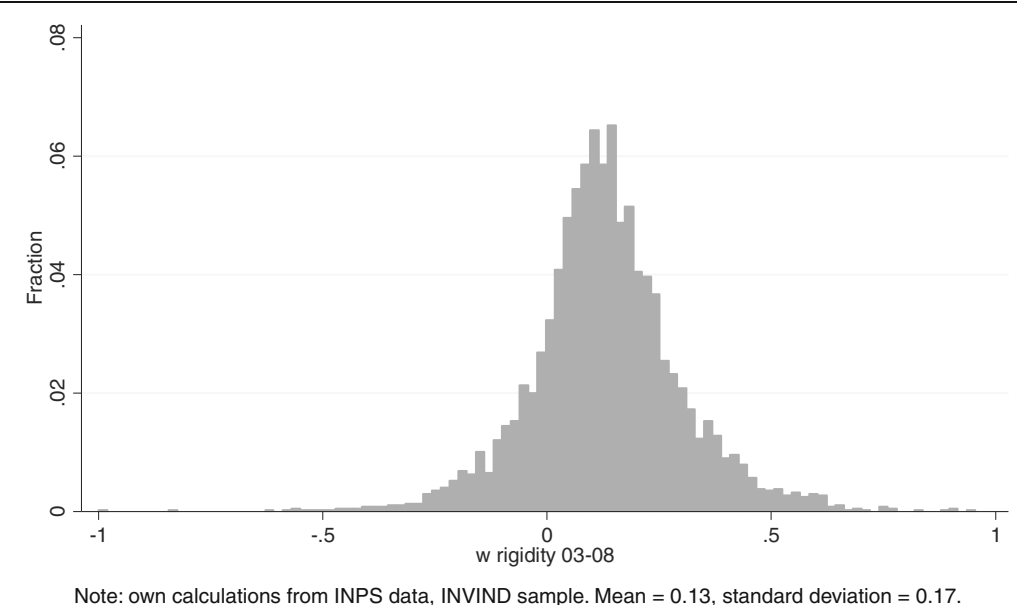

Fig. 13 Distribution of firm level wage rigidity (Kelley's skewness, 2003-2008)

Table 3 shows the determinants of our measure of wage rigidity. Column 1 shows that larger firms, whose average wages are less often flattened upon the national contractual wages, tend to be less rigid, which is in line with the results of Adamopoulou et al. (2016) and with those in Section 4. Again in line with the results of our previous section, column 2 shows that firms are less rigid if they are characterized by a high share of blue collars. Column 3 shows instead that our measure of wage rigidity is not related with the amount of overtime hours employed by each firm. This suggests that wages are not flexible simply because of the firms' ability to adjust overtime hours. Column 4 shows that there is a positive association between firms' productivity and firms' rigidity. This result is consistent with the theory of efficiency wages (Akerlof 1982; Stiglitz 1986; Campbell and Kamlani 1997). Firms may decide not to cut wages because wage cuts reduce workers' effort and overall productivity. Productivity would therefore be positively associated with higher level of rigidity both because workers not experiencing a wage cut are more productive and because more productive, and profitable, firms may have enough

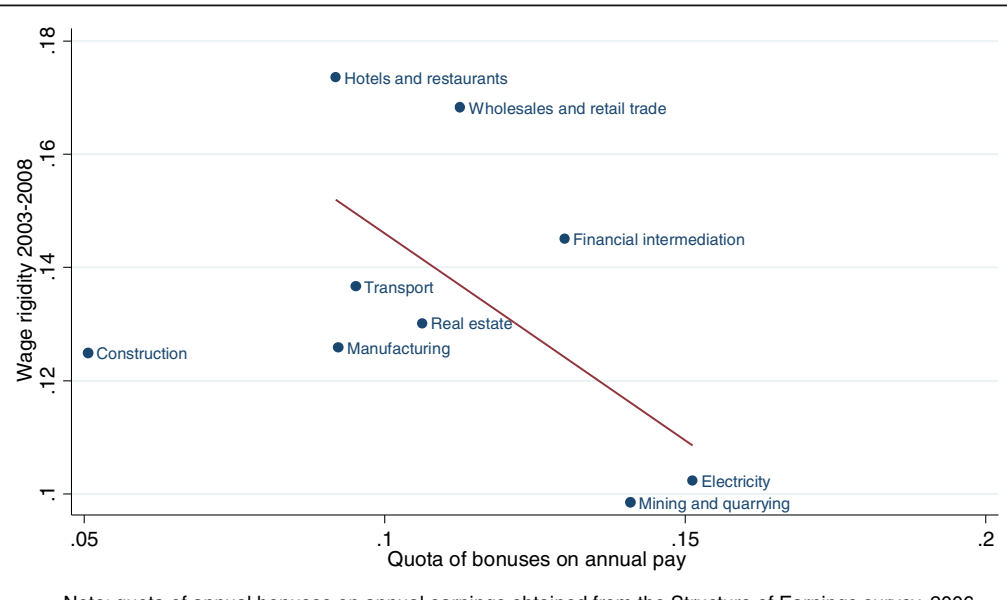

Note: quota of annual bonuses on annual earnings obtained from the Structure of Earnings survey, 2006. The fitting line is computed excluding the construction sector.

Fig. 14 Wage rigidity and share of bonuses at the sector level 


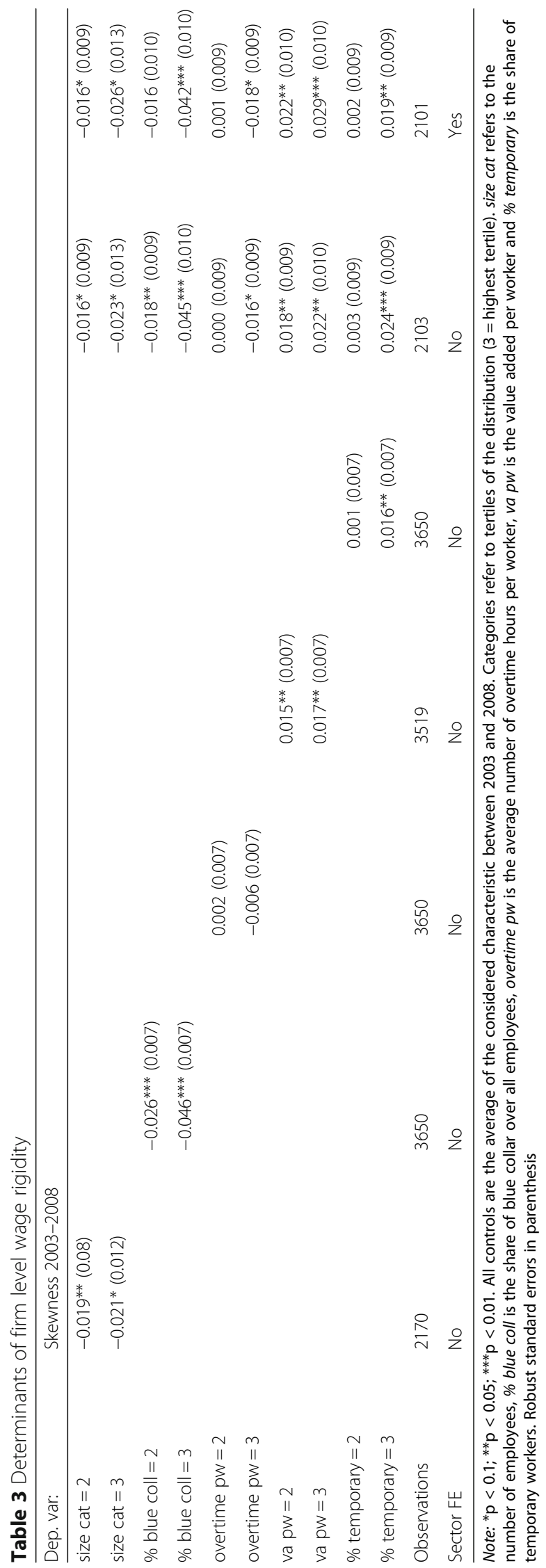


resources to decide not to cut wages. Finally, column 5 shows that firms with a high share of temporary workers tend to be more rigid: we interpret this as a sign that rigid firms, envisaging their difficulty in adjusting wages of job stayers, react by hiring a large share of temporary workers, easier to fire.

Lastly, we conducted a robustness check in order to verify that observing daily instead of hourly wages does not undermine our results of Section 4. We use the information provided by the INVIND survey on the amount of overtime hours per capita in 2008 (i.e. before the crisis) at the firm level and we classify firms into more and less overtime-intensive (above and below the median). We then compute the skewness of the distribution of annual changes of daily wages for all workers belonging to each group of firms for the years 2006 and 2009. We find that for both groups, the skewness was almost identical in 2006 and it declined sharply in 2009 by almost the same amount (Fig. 15). Therefore, we conclude that overtime hours do not seem to drive the observed increase in wage flexibility in 2009.

In the next section, we study how firms characterized by different levels of wage rigidity respond to the recent recession.

\subsection{Firms' wage rigidity and employment adjustments}

We perform regressions at the firm level to evaluate the relationship between the measure of wage rigidity described above and firms' adjustments in the employment margin and in their average wage per employee during the recent recession.

We estimate the following equation:

$$
\Delta y_{i, t-08}=\alpha+\beta \text { skewness }_{i}+\gamma X_{i}+\varepsilon_{i}
$$

where $y_{i, t-08}$ are flows of the outcome variables during the recent recession (between 2008 and $t=2009,2011$ and 2013); in particular, we look at: turnover $\left(\frac{\text { accessions }_{t}+\text { separations }_{t}}{\text { employment }_{2008}}\right)$; accessions $\left(\frac{\text { accessions }_{t}}{\text { employment }_{2008}}\right)$; separations $\left(\frac{\text { separations }_{t}}{\text { employment }_{2008}}\right){ }^{20}$; the increase in the average wage per year per employee $\left(\frac{\mathrm{av} \mathrm{wage}_{t}}{\mathrm{av} \mathrm{wage}_{2008}}-1\right)$ and the probability of exiting the market. skewness $i$ is the Kelley's skewness measure that refers to the 6 years before the recession, as described in Section 6.1.

Since we want in principle to isolate the effect of wage rigidity from the effect of other factors such as the firm size, that may be associated with both a more flexible wage structure and different dynamics of our dependent variables, we control in all specifications for firms' value added per worker, firms' age, size, level of overtime hours per employee, share of temporary workers, province and sector of activity. All controls refer to the year 2008, i.e. right before the arrival of the crisis, in order to exclude endogenous changes of these variables correlated with the effect of interest. Moreover, in some specifications, we include the variation of total sales during the recession as additional control, in order to correct for the heterogeneity of the shocks across firms. Standard errors are clustered at the firm level. ${ }^{21}$

Therefore, the $\beta$ coefficient of our regressions measures the relationship between wage rigidity at the firm level and employment adjustments, net of the effect of other potential (observable) factors that may spur our estimate. ${ }^{22}$ 
Table 4 displays the main descriptive statistics. Firms in the INVIND sample mostly belong to the industrial sector and are of rather large dimension. Temporary workers represent on average $7 \%$ of their workforce. Average turnover in 2009 was $20 \%$ with respect to the number of employees in 2008 and separations were slightly larger than accessions.

Table 5 presents our main results on turnover. In line with Devicienti et al. (2007), we find that firms with higher wage rigidities are characterized by higher turnover in 2009 (column 1). In particular, an increase in the firm-level skewness by one standard deviation (0.16) is associated with a turnover rate in 2009 of almost 0.7 percentage points higher. One may worry about possible omitted variables in this regression. In particular, it may be that more rigid firms may be hit

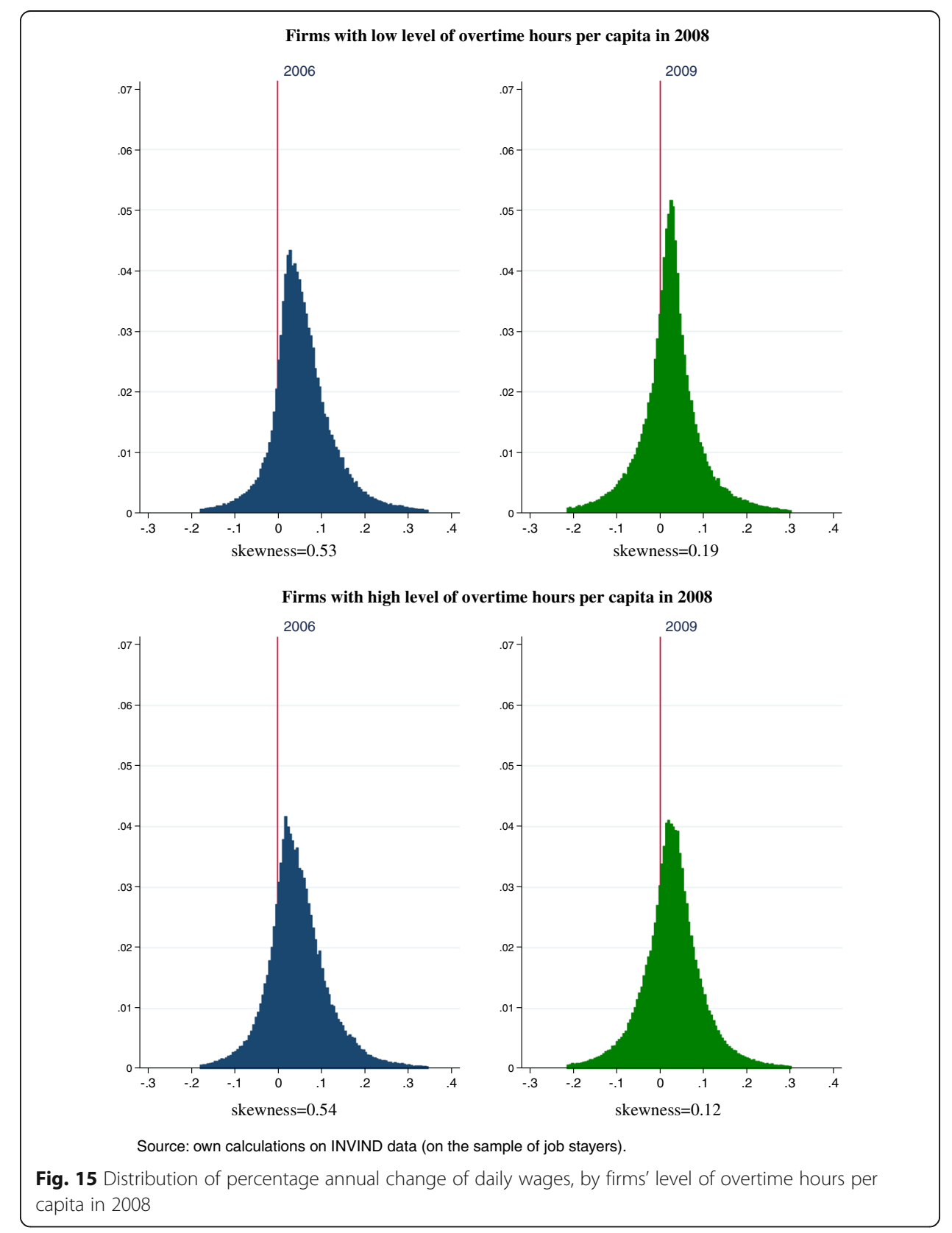


Table 4 Descriptive statistics of INVIND firms: mean and standard deviation

\begin{tabular}{|c|c|c|}
\hline Characteristics & Mean & s.d. \\
\hline Skewness $2003-2008$ & 0.138 & 0.161 \\
\hline Turnover $_{2009}$ & 0.194 & 0.258 \\
\hline$\%$ Accessions $_{2009}$ & 0.087 & 0.142 \\
\hline$\%$ Separations 2009 & 0.107 & 0.132 \\
\hline Turnover $_{2011}$ & 0.579 & 0.751 \\
\hline$\%$ Accessions $_{2011}$ & 0.276 & 0.391 \\
\hline \% Separations 2011 & 0.300 & 0.365 \\
\hline Turnover $_{2013}$ & 0.905 & 1.198 \\
\hline$\%$ Accessions $_{2013}$ & 0.439 & 0.629 \\
\hline$\%$ Separations $_{2013}$ & 0.466 & 0.585 \\
\hline$\% \Delta(\text { firm's average wage })_{2009}$ & -0.010 & 0.080 \\
\hline$\% \Delta$ (firm's average wage $)_{2011}$ & 0.061 & 0.089 \\
\hline$\% \Delta$ (firm's average wage $)_{2013}$ & 0.092 & 0.119 \\
\hline \% Temporary employees 2008 & 0.068 & 0.115 \\
\hline Firm size 2008 & 468 & 2152 \\
\hline$\%$ Industry & 0.760 & - \\
\hline Firm age 2008 & 25.89 & 13.15 \\
\hline Value added per worker 2008 & 71.09 & 74.28 \\
\hline Overtime hours per worker 2008 & 5336 & 3062 \\
\hline$\% \Delta$ (sales) 2009 & 0.068 & 0.115 \\
\hline
\end{tabular}

Source: The skewness is taken from INPS data on the population of workers belonging to firms in the INVIND sample. Turnover, accessions, separations, share of temporary workers, overtime hours per worker and sales from the INVIND survey. Average wage, firm size, age and sector from INPS data on the population of firms. Value added per worker from CERVED. Turnover 2011 , accessions ${ }_{2011}$ and separations ${ }_{2011}$ are cumulative for the years 2009-2011, turnover 2013 , accessions $_{2013}$ and separations ${ }_{2013}$ are cumulative for the years $2009-2013$. All variables in $\% \Delta$ are defined with 2008 as base year

differently by the crisis. Column 2 shows that the results are robust to the inclusion of the percentage change of sales, our proxy for the size of the firm-level shock. However, this control of the demand shock is potentially endogenous, as it refers to 2009 and may be considered as an outcome itself. We therefore exclude it from our preferred specification. We also examine whether the effect of wage rigidities persists over time by considering turnover in 2011 and in 2013 (computed as the cumulative rate of accessions and separations with respect to 2008). Indeed, the effect is still present and increasing both in 2011 and 2013. This may be reconciled with a delayed employment adjustment for firms that start exhausting any margin of wage adjustment.

At this point, it is crucial to understand the nature of this increased turnover. In particular, it is interesting to explore whether it is mainly driven by separations or accessions and which may be the channel behind it. One possible mechanism acts through the increased turnover of temporary workers (see Bulligan and Viviano, 2016). Firms that are constrained by wage rigidities may exploit the turnover of temporary workers either to renegotiate their wage or to hire a different worker, whose wage will reflect the new cyclical conditions. In this way, firms can exploit flexibility on the employment margin in order to adjust their average labour cost. 


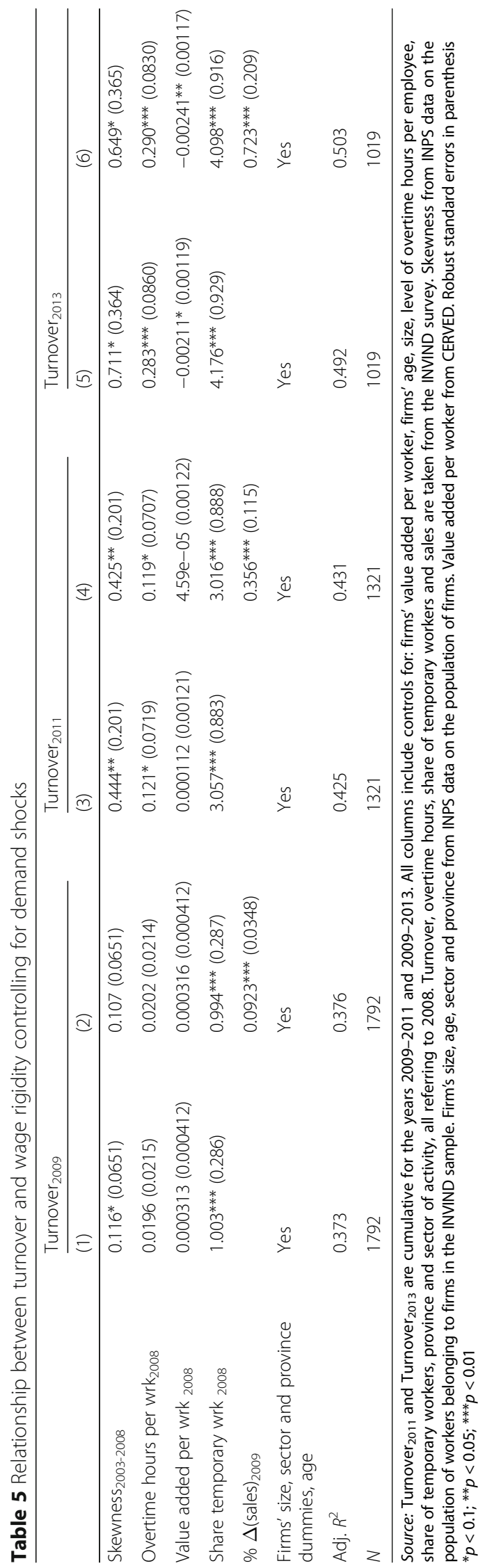


The INVIND data allow us to distinguish whether the effect on turnover is driven by accessions, separations or both. Tables 6 and 7 present separately the results for accessions and separations as a share of employment in 2008. We distinguish between firms with high and low share of temporary workers in 2008 in order to understand whether the proposed mechanism may be at work. ${ }^{23}$ We find that firms that are characterized by higher wage rigidities tend to hire but also to fire more in 2009 as well as in 2011 and 2013. Moreover, we find that this effect comes mostly from firms with a high share of temporary workers (columns 2, 4 and 6) than from firms with a low share of temporary workers (columns 1, 3 and 5), even if very rigid. ${ }^{24}$ Note that the coefficient of skewness related to the accessions is larger than the one related to separations. This may be because separations do not include only firings but also voluntary quits or other types of job termination. If wage cuts operated by less rigid firms led to voluntary quits of workers who did not want to accept them, then overall separations should be large in flexible firms as well. Since our coefficient compares the effect of more and less rigid firms on overall separations, the difference may be smaller for separations exactly because flexible firms display larger quit rates during the recession as well. At the moment, we cannot verify this explanation because our data do not contain information on separations net of voluntary quits.

Lastly, we use information on the average wage per employee paid by the firm (available in the INPS data for the universe of firms) to test whether in the presence of wage rigidities, the temporary-worker channel allowed firms to decrease the average wage indirectly. Table 8 shows the results. As expected, more rigid firms (with higher value of skewness) adjusted their average wage less: the changes in average wage are more positive for rigid firms during the recession. However, firms with a higher share of temporary workers managed to adjust wages more. This is true both in 2009 and 2011. In 2013, the signs are reverted. We believe that this is due to sample selection/survivor bias that spurs our results. ${ }^{25}$ We conclude that firms managed, through the use of temporary workers, to partly contain their labour cost per employee even in the presence of wage rigidities.

\section{Conclusions}

In this paper, we document the evolution of wage rigidities over time in Italy and we find that during the recent recession wage flexibility has increased. We study the various channels though which daily-wage adjustments were enacted and we reveal that the part of the wages that is not nationally negotiated responded more to the adverse cyclical conditions. Other main determinants of wage flexibility are the incidence of bonuses over total earnings, the share of blue collar workers and the firm size. Although we only observe daily and not hourly wages, overtime hours did not seem to be the main driver behind the observed wage developments.

We also conduct an analysis at the firm level and we identify firms that were historically characterized by different levels of wage rigidities in order to study their behaviour during the crisis. We find that there is a wage employment trade-off also as far as their adjustment is concerned: firms structurally characterized by higher wage rigidity adjusted more often along the employment margin by increasing their turnover in the period 2009-2013. These larger employment adjustments were mostly driven by rigid 


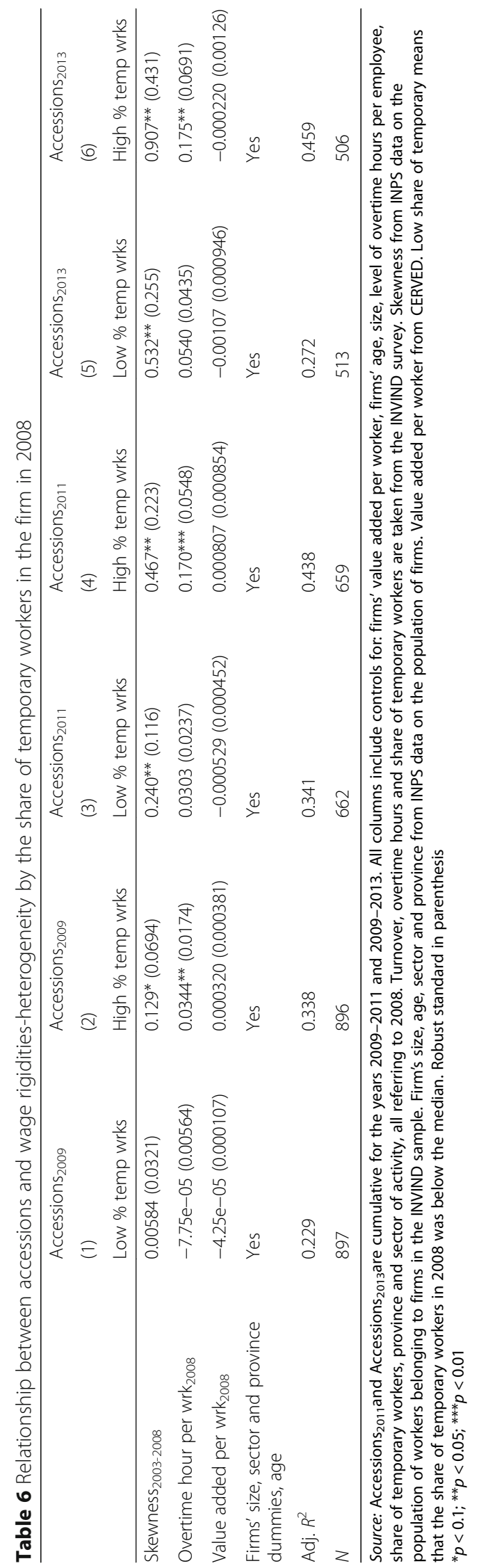




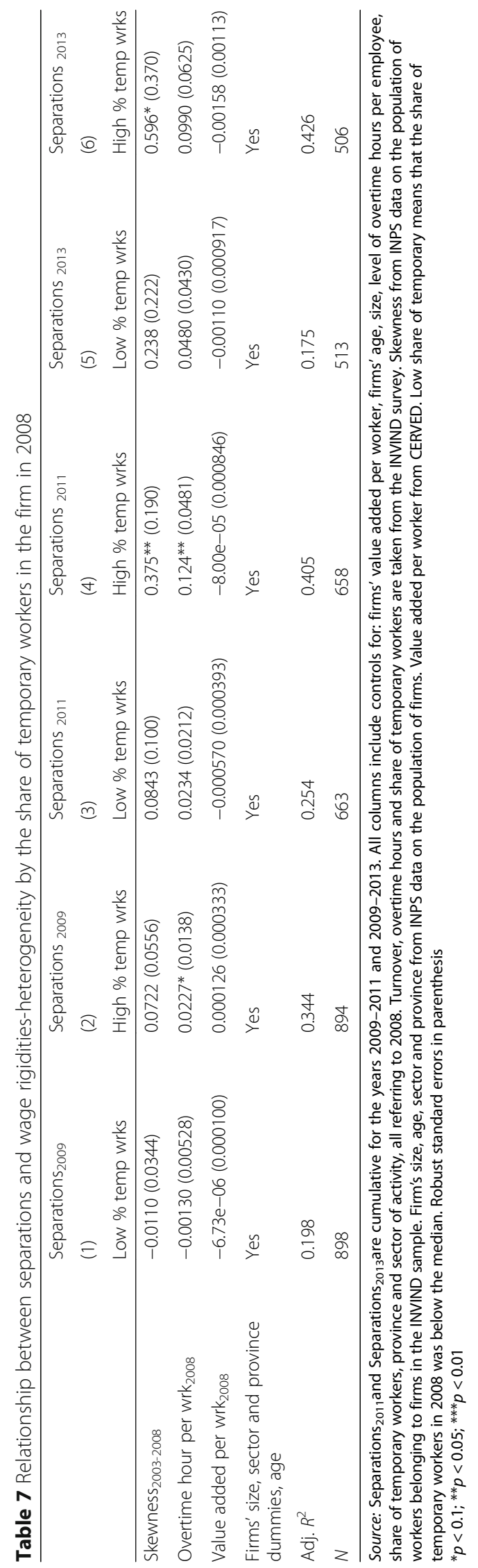




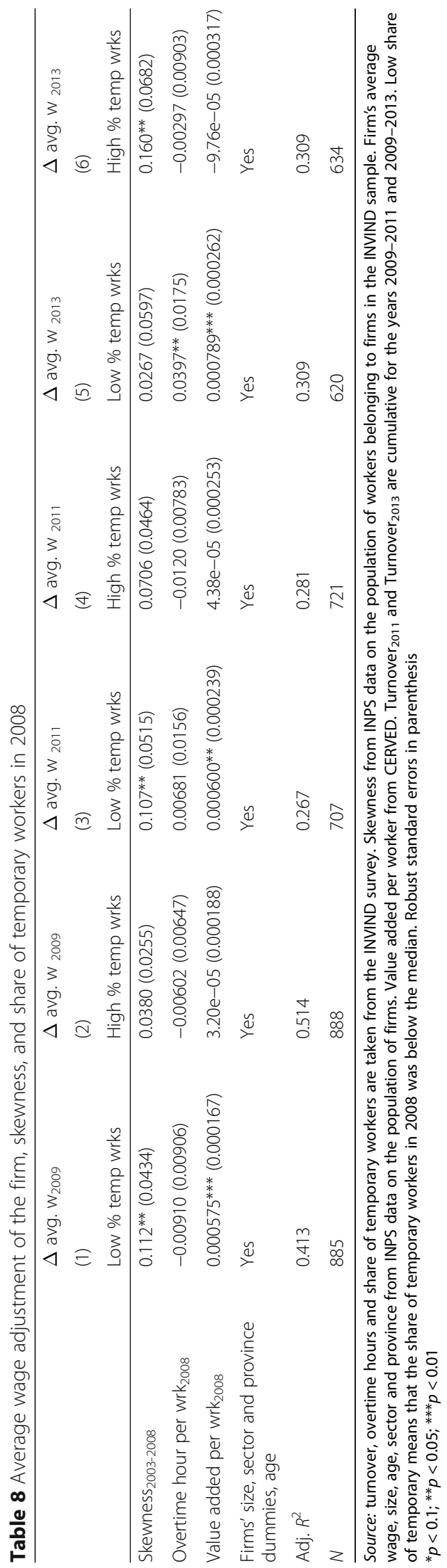


firms with a high enough share of temporary workers, easier to fire. Moreover, we find that the average wage per employee of rigid firms adjusted less during the crisis but that those firms endowed with a larger portion of temporary workers managed to partly compress their average labour cost in any case. Our conjecture is that these firms managed to deal with the challenges of the recessionary conditions not by directly reducing wages of job stayers but by indirectly containing the labour cost through firing of temporary workers and hiring of new ones with lower salaries. This source of flexibility through temporary workers allowed firms to survive in a rigid institutional setting. Reforms of the latter may reduce the need of using temporary workers as a flexibility margin during downturns.

Our study provides some evidence on wage adjustments in Italy during the Great Recession and on the way firms reacted differently to the crisis. However, it does not quantify how much this increased flexibility contributed to helping firms absorb the negative shocks and its overall implications for the economy. We leave this question, of high policy relevance but which requires additional assumptions in order to construct a proper counterfactual, to future research.

\section{Endnotes}

${ }^{1}$ Given that firms characterized by a rigid wage structure may choose to hire more temporary workers as a response to the crisis, we evaluate the heterogeneity of the effect based on the firms' stock of temporary workers before the crisis in order to classify them.

${ }^{2}$ While the INPS data do not provide us with the information on the different components making up wages, for some sectors, we were able to find occupation-specific information on the nationally negotiated base salaries (see Section 5) and to distinguish the evolution of the nationally negotiated part from the remaining part of the wage, which includes bonuses (also agreed through firm level negotiations) and overtime among other things.

${ }^{3}$ Before 1993, the wage inflation adjustment was practically automatic through an indexation mechanism. The abolition of this mechanism was found to be associated with a decline in downward real wage rigidities (Devicienti et al., 2007).

${ }^{4}$ In line with the predictions of existing models (Postel-Vinay and Robin, 2004; Gertler and Trigari, 2009), we observe that wages of job movers and new entrants respond more to the cycle. In the rest of the section, we focus on job stayers, whose wages are, in general, more stable.

${ }^{5}$ This is the annual total gross wage, net of firms' social security contributions.

${ }^{6}$ Note that we consider daily wages, but since we only take the sample of the socalled super stayers, these are variations coming from variations in annual wages not in days per year. The figures we find are indeed very similar if we look at the variations in annual wages for our sample.

${ }^{7}$ That is the distribution of delta wages when wages are fully flexible.

${ }^{8}$ These are firms belonging to the Bank of Italy INVIND sample of 20 or more employees.

${ }^{9}$ In line with Verdugo (2016) and Elsby et al. (2016).

${ }^{10}$ The large drop observed in 1993 is likely to be due to the abolition of the wage indexation mechanism (see the next section and Devicienti et al., 2007 for more details). 
${ }^{11}$ The excess growth observed in 2008 partially reflected the renewal of several major collective contracts that also involved one-off payments in order to compensate for unusually long delays in their renewal (e.g. around 300 euros to metalworkers).

${ }^{12}$ The large drop in the skewness observed in 1998 for the construction workers may be related to the introduction of apprenticeships.

${ }^{13}$ Bonuses of this type are usually determined through firm-level bargaining that is not widespread among smaller firms.

${ }^{14}$ Unfortunately INPS data do not contain information about the presence of a firm level agreement with social parties, so we cannot analyse this aspect. However, firmlevel agreements are not very widespread in Italy: according to the INVIND survey of the Bank of Italy, in 2010 only around 20 per cent of medium/large firms (of more than 20 employees) engaged in some form of firm-level negotiations.

${ }^{15}$ Source: Diritto and Pratica del Lavoro and http://www.cnel.it/home.

${ }^{16}$ Both contracts were renewed in 2008, before the hit of the crisis.

${ }^{17}$ Even before 1993, when the indexation mechanism was in place, there was evidence of the existence of a compensating differential between the indexed and the nonindexed part of the wage (see Manacorda, 2004). For Scandinavian countries, Hibbs and Locking (1996) and Holden (1998) find that increases in nationally negotiated wage have little offsetting effect on wage drift.

${ }^{18}$ Ideally, we would like to observe hourly wages and not just daily wages. In the absence of hours worked, controlling for overtime hours allows us to partially exclude the possibility that the adjustment of daily wages is operated exclusively through the adjustment of overtime hours.

${ }^{19}$ We performed various robustness exercises around the absolute and relative threshold of the number of job stayers in the window [60, 100] (and [60\%, 80\%]), and the results were very similar.

${ }^{20}$ Where accessions and separations are computed as the sum of all accessions that took place between 2008 and $t$.

${ }^{21}$ We start with a sample of around 4000 firms in 2009 and we are left with less than 2000 firms for which the skewness, the turnover measures and all the controls are not missing. This reduction in the sample is mainly due to the fact that we lose quite a few observations by restricting the sample to firms that we observe both in the period 2003-2008 and in all the years between 2009 and 2013. Moreover, we dropped around 60 firms that we could not match with the INPS data and around 60 firms for which the employment data from INPS and INVIND displayed great discrepancies.

${ }^{22}$ Note that the $\beta$ obtained with our specification is very similar to the $\beta$ obtained

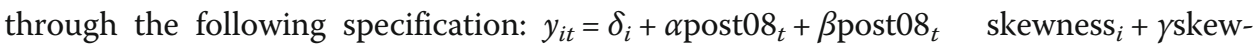
ness $_{i}+u_{i t}$ (by taking the difference between $t$ and 2008 of the previous equation, we obtain Eq. 1). With our specification, however, it is easier to evaluate how the effect evolved over time by just changing the reference period $t$ of our dependent variable $\Delta y_{i, t-08}$.

${ }^{23}$ Another alternative mechanism is that, being the temporary workers usually younger and less experienced, they are paid less on average and they therefore have a higher probability of being paid the national wage. It may therefore be more likely to fire temporary workers just because they belong to the set of workers for whom it is not 
possible to cut wage further and not because of their type of labour contract (and associated firing costs). We find however that, even controlling for the average wage level in 2008 (which proxies the share of workers close to the contractual minimum threshold), the turnover is much higher in firms characterized by a higher share of temporary workers in 2008 (results available upon request).

${ }^{24}$ Firing is very difficult for firms with more than 15 employees in Italy.

${ }^{25}$ Additional estimates (available upon request) indicate that more rigid firms have a higher probability of exiting the market in 2013. This would entail that the samples of more rigid firms with and without temporary workers are not fully comparable in 2013.

\section{Acknowledgements}

Many thanks to an anonymous referee and the editor, Matteo Bugamelli, Francesco D'Amuri, Raffaella Nizzi, Alfonso Rosolia, Paolo Sestito, Eliana Viviano and seminar participants at the Bank of Italy for useful comments and help. The views expressed in this paper are those of the authors and do not necessarily reflect those of the Bank of Italy. Responsible editor: Juan Jimeno

\section{Competing interests}

The IZA Journal of Labor Policy is committed to the IZA Guiding Principles of Research Integrity. The authors declares that they have observed these principles.

Received: 22 June 2016 Accepted: 24 November 2016

Published online: 28 December 2016

\section{References}

Adamopoulou E, Bobbio E, De Philippis M, Giorgi F (2016) Allocative efficiency and aggregate wage dynamics in Italy, 1990-2013. In: Bank of Italy Occasional Paper., p 340

Akerlof GA (1982) Labor contracts as partial gift exchange. Q J Econ 97:543-569

Brandolini A and Rosolia A (2015) The Euro area wage distribution over the crisis. Banca d'Italia, Rome Mimeo

Bulligan G, Viviano E (2016) Has the wage Phillips curve changed in the Euro area? Evidence from four countries. In: Banca d'Italia occasional working paper., p 355

Campbell C, Kamlani K (1997) The reasons for wage rigidity: evidence from a survey of firms. Q J Econ 112:759-789

Cappellari L, Dell'Aringa C, Leonardi M (2012) Temporary employment, job flows and productivity: a tale of two reforms. Econ J 122:188-215

Card D and Hyslop D (1997) Does inflation "grease the wheels of the labor market?" In: Romer C and Romer D (eds) Reducing Inflation: Motivation and Strategy, vol 30. National Bureau of Economic Research Studies in Business Cycles, Cambridge

D’Amuri F (2014) Composition effects and wage dynamics in Italy. Banca d'Italia, RomeMimeo

Daly M, Hobijn B, Wiles T (2011) Dissecting aggregate real wage fluctuations: individual wage growth and the composition effect. In: Federal Reserve Bank of San Francisco., p 23

D'Amuri F, Fabiani S, Sabbatini R, Tartaglia Polcini R, Venditti F, Viviano E, Zizza R (2015) Wages and prices in Italy during the crises: the firms' perspective. In: Bank of Italy Occasional Papers., p 289

Devicienti F, Maida A, Sestito P (2007) Downward wage rigidity in Italy: micro-based measures and implications. Econ J 117:F530-F552

Dickens W, Goette L, Groshen E, Holden S, Messina J, Schweitzer M, Turunen J, Ward M (2007) How wages change: micro evidence from the International Wage Flexibility Project. J Econ Perspect 21(2):195-214

Ehrlich G and Montes J (2015) Wage rigidity and employment outcomes: evidence from German administrative data. University of Michigan, Ann ArborMimeo

Elsby M, Shin D, Solon G (2016). Wage adjustment in the great recession and other downturns: evidence from the United States and Great Britain. J Labor Econ. Forthcoming. http://www.journals.uchicago.edu/doi/abs/10.1086/ 682407.

Eurostat (2002). "Statistical Classification of Economic Activities in the European Community, Rev.1.1 (2002) (NACE Rev. 1.1)", Luxembourg.

Gertler M, Trigari A (2009) Unemployment fluctuations with staggered Nash wage bargaining. J Polit Econ 117:38-86 Goette L, Sunde U, Bauer TK (2007) Wage rigidity: measurement, causes and consequences. Econ J 117:469-477 Guvenen F, Ozkan S, Song J (2014) The nature of countercyclical income risk. J Polit Econ 122:621-660

Hibbs DA Jr, Locking H (1996) Wage compression, wage drift and wage inflation in Sweden. Labour Econ 3:109-141 Holden S (1998) Wage drift and the relevance of centralised wage setting. Scand J Econ 100:711-731

Holden S, Wulfsberg F (2008) Downward nominal wage rigidity in the OECD. B E J Macroecon (Advances) 8(1):15

Kahn S (1997) Evidence of nominal wage stickiness from microdata. Am Econ Rev 87:993-1008

Knoppik C, Beissinger T (2009) Downward nominal wage rigidity in Europe: an analysis of European micro data from the ECHP 1994-2001. Empir Econ 36:321-338

Kurmann A, McEntarfer E, Spletzer J (2014). The nature of wage adjustment in U.S. firms: new evidence from workerfirm linked data. Drexel University, Philadelphia Mimeo

Lemieux T (2006) Increasing residual wage inequality: composition effects, noisy data, or rising demand for skill? Am Econ Rev 96:461-498 
Manacorda M (2004) Can the scala mobile explain the fall and rise of earnings inequality in Italy? A semiparametric analysis, 1977-1993. J Labor Econ 22:585-613

Pischke JS (2016) Wage flexibility and employment fluctuations: evidence from the housing sector. In: NBER Working Paper., p 22496

Postel-Vinay F, Robin JM (2004) To match or not to match? Optimal wage policy with endogenous worker search intensity. Rev Econ Dyn 7:297-331

Stiglitz JE (1986) Theories of wage rigidity. In: Butkiewicz J, Koford K, Miller J (eds) Keynes' Economic Legacy: Contemporary Economic theories. Praeger Publishers, New York, pp 153-206

Verdugo G (2016) Real wage cyclicality in the Euro zone before and during the Great Recession: evidence from micro data. Eur Econ Rev 82:46-69 